\title{
Capital Controls: Gates versus Walls
}

ABSTRACT This paper examines the pattern of controls on cross-border capital inflows and their association with measures of financial vulnerability, GDP, and exchange rates. A key distinction is made between long-standing controls that cover a broad range of assets (walls) and episodic controls that tend to be imposed on a narrower set of assets (gates). The paper presents a new data set that differentiates between controls on inflows and on outflows as well as among asset categories for 44 developed and emerging market economies over 1995-2010. The imposition of episodic controls is found not to have followed the prescriptions of theories that suggest first imposing controls on those inflows most likely to contribute to financial vulnerability. Estimates show significant differences in the partial correlations of long-standing and episodic controls with the growth of certain financial variables and with GDP growth, but these differences seem to arise because countries with long-standing controls are poorer on average than the other countries in the sample. With a few exceptions, estimates that control for GDP per capita find little evidence that capital controls affect the growth of these financial variables, the real exchange rate, or GDP growth at an annual frequency. These preliminary results raise doubts about assumptions behind recent calls for a greater use of episodic controls.

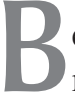

efore 2008, the prevailing (but not universal) view among economists was that a country generally benefits from allowing the free flow of assets across its borders. ${ }^{1}$ This was thought to be especially true of middle-income emerging market economies, which tend to have an abundance of funding opportunities relative to domestically generated savings. International asset diversification could also benefit savers in these countries, where domestic productive activities tend to be concentrated within a limited range of industries. Capital flows to emerging markets were also

1. For example, see Sachs and Warner (1995), Dornbusch (1998), Summers (2000), and Fischer (2003). Around that time, others voiced concerns about international capital flows and doubts about the positive effects of capital account liberalization, including Bhagwati (1998), Rodrik (1998), and Stiglitz (2002). 
considered a means for the transfer of financial know-how that could spur development in countries hobbled by rudimentary financial markets. Theoretical and empirical research supported these views, which were also reflected in practice: a wave of countries dismantled controls on capital flows in the 1980s and 1990s, and few had reimposed controls by the turn of the century.

This decades-long trend has shifted. Some countries that had liberalized their capital accounts began to reintroduce controls in the early 2000s. This retrenchment increased after the onset of the Great Recession, when new controls on capital inflows were imposed, and existing ones tightened, by a number of emerging market and developed economies alike, including Brazil, Iceland, Ireland, Peru, and Turkey. These measures were put in place to address concerns about inflow-fueled appreciation of the domestic currency and potentially destabilizing asset price booms.

These shifts in practice have been accompanied by shifts in opinion. As early as 2002, the International Monetary Fund (IMF) had begun to soften its preference for unfettered international asset movements. In that year Kenneth Rogoff, then serving as chief economist and director of research at the IMF, wrote in the December issue of the IMF's Finance and Development, "These days, everyone agrees that a more eclectic approach to capital account liberalization is required" (Rogoff 2002, p. 55). More recently, the IMF staff has published position papers that accept a role for capital controls. ${ }^{2}$ Although the current IMF position is that capital controls become an option only after other policy choices have been exhausted, Olivier Jeanne, Arvind Subramanian, and John Williamson (2012, p. 95) argue that they should not be a last resort, but rather that "properly designed they might even be a regular instrument of economic policy." This argument is bolstered by recent theory that highlights the prudential role of capital controls whereby temporary, pro-cyclical, welltargeted controls contribute to financial stability. ${ }^{3}$

Evolving practices and prescriptions make this an opportune time to reconsider the role of capital controls. This paper analyzes experience with controls on capital inflows for 44 countries over the period 1995-2010. The analysis uses a new data set that, unlike earlier cross-country capital controls data, differentiates between controls on inflows and on outflows.

2. See Ostry and others (2010, 2011a) and IMF Strategy, Policy and Review Department (2011).

3. For example, see Korinek (2010), Jeanne and Korinek (2010), Bianchi and Mendoza (2010), and Jeanne (2012). 
This distinction is of obvious importance when considering the association between capital controls and currency appreciations or asset price booms. This data set also includes separate measures of inflow controls on six categories of assets, which is especially important for considering the prudential role of capital controls because of differences in the perceived vulnerabilities from inflows of different types of assets (for example, shortmaturity debt as compared with long-term direct investment).

A central theme of this paper is the distinction between the effects of long-standing and of episodic controls on capital flows. This distinction may have been less apparent 15 years ago than today, because, in general, there were few instances of the reimposition of controls through the mid1990s. Currently some countries, such as China, continue to have longstanding capital controls, but other countries have reintroduced controls when events seemed to warrant their use. For example, on October 20, 2009, the Brazilian government imposed a 2 percent tax on investment in existing Brazilian equities (the Imposto sobre Operações Financeiras, or IOF), which was then raised to 4 percent on October 5, 2010, and to 6 percent less than 2 weeks later. This is a particularly prominent example because in late September 2010, the Brazilian finance minister, Guido Mantega, declared that an "international currency war" had broken out as a result of U.S. monetary policy ("Brazil in Currency War Alert," Financial Times, September 27, 2010).

Long-standing capital controls are like walls that attempt to erect a more or less permanent barrier against the vicissitudes of international capital markets. As will be shown, these walls tend to be wide as well as high, limiting all manner of capital flows, including those that could provide cheap capital, financial development, and opportunities to diversify risk. In contrast, episodic capital controls open like gates during tranquil times, to enable an economy to benefit from international capital, but swing shut in the face of capital inflows that threaten to cause an unwanted appreciation or a destabilizing asset market boom. These episodic controls, because they are transitory and usually targeted toward particular categories of assets, are less distortionary and inefficient than broad, long-standing controls.

One problem with gates, however, is that they might not shut tightly. Episodic controls are likely to be less efficacious than long-standing controls because evasion is easier in a country that already has experience in international capital markets than in one that does not. In addition, governments in countries with long-standing controls are likely to have incurred the sunk costs required to establish an infrastructure of surveillance, reporting, and enforcement that makes those controls more effective. People in countries 
with long-standing controls also tend to have fewer options for evasion because domestic financial markets are less developed, and because controls are imposed on a wider set of assets than in countries with episodic controls. Another problem with gates is that they may shut too late. It may be difficult to gauge the appropriate moment to implement episodic capital controls, and implementation itself may take some time. Finally, political factors may make it difficult to shut the gates. To borrow William McChesney Martin's well-known metaphor for monetary policy, the role of prudential controls on capital inflows is to take away the punchbowl just as the party gets goingbut the revelers may resist having their drinks confiscated.

Statistics presented in this paper show that countries closed to capital inflows do, on average, have lower annual rates of growth of certain financial variables associated with asset price booms, and higher rates of growth of GDP. Regression results also show that, in partial correlations, the growth of these aggregate variables is statistically significantly slower in countries with long-standing controls than in countries that have episodically imposed controls. But countries with long-standing controls differ in important ways from the other countries in the sample: most notably, they tend to have much lower GDP per capita. When this difference is controlled for, the partial correlations suggest that neither long-standing nor episodic controls are associated with slower annual growth of financial variables or of GDP or with lower rates of currency appreciation.

Section I of this paper begins with a brief discussion of the role of capital flows in international macroeconomics and an overview of the theory of the effects of capital controls. This section also includes a brief discussion of the long history of capital controls and introduces the data set used in the subsequent analysis. The 44 countries in the data set are divided into three categories: those persistently open to inflows, those persistently closed to inflows, and those with episodically imposed controls on inflows. The section closes with a discussion of the pattern of inflow controls across asset categories. Section II presents empirical results that show the association of both long-standing and episodic capital controls with changes in financial variables that could presage a boom-bust cycle, with GDP growth, and with the real exchange rate. The final section offers some concluding remarks.

\section{Capital Controls in Theory and Practice}

Capital controls are rules, taxes, or fees associated with financial transactions that discriminate between domestic residents and nonresidents (Organisation for Economic Co-operation and Development 2009, cited in Ostry 
and others 2012). The controls can be administrative or market-based. Administrative controls include outright prohibitions on foreign borrowing or lending, quantitative limits on these transactions, and the requirement that such transactions receive prior government approval. Market-based measures include taxes on cross-border capital transactions, differential bank reserve requirements for resident and nonresident accounts, and the requirement that some proportion of capital inflows be deposited in a non-interest-bearing account at a central bank (an unremunerated reserve requirement), which effectively serves as a tax on inflows. Unlike tariffs on goods and services, which are subject to the multilateral General Agreement on Tariffs and Trade (GATT), countries are generally free to impose or remove capital controls without reference to international agreements. ${ }^{4}$

\section{I.A. Capital Controls in Theory}

Long-term international borrowing and lending offers several distinct economic benefits to the countries on both sides of the transaction (Obstfeld and Rogoff 1996, chapters 1, 3, and 5). Foreign investment, whether in the form of international equity or debt, can both increase the amount of productive capital in the host country and raise the returns earned by investors in the source country. These international transactions also afford diversification opportunities to domestic savers, which have potentially large effects on welfare by allowing for a smoother path of consumption as well as by raising the willingness of domestic producers to undertake risky projects (Obstfeld 1994). Foreign direct investment, as occurs when a firm builds a factory in another country or establishes a financial subsidiary there, may foster technology transfer and promote financial development in the host country. The implication of these arguments is that long-lasting capital controls, by preventing these transactions, hamper growth, development, and economic welfare.

Shorter-run capital flows are at the heart of the analysis of business cycles in international macroeconomics. The equalization of expected returns to bonds denominated in different currencies (uncovered interest parity) is central to the policy trilemma, whereby economic policymakers

4. An exception is that some countries face restrictions on imposing capital controls because of bilateral investment treaties (BITs) they have entered into with the United States. Spillover effects, which arise when one country's imposition of capital controls affects another country, perhaps by diverting funds to that country, are one reason for international cooperation on capital controls. Jeanne, Subramanian, and Williamson (2012) argue for such cooperation. Forbes and others (2012) present evidence that the Brazilian capital controls altered investors' portfolio allocations. 
can choose at most two of the following three: monetary policy independence, exchange rate management, and international capital mobility. ${ }^{5}$ Unfettered capital mobility presents monetary authorities with the choice of targeting either the domestic interest rate or the exchange rate. Capital controls, however, may provide scope for policy to independently achieve both an interest rate target and an exchange rate target by preventing capital flows that respond to domestic interest rates and influence the value of the domestic currency. Controls would thus enable the monetary authorities to address "internal" goals, such as low unemployment and low and stable inflation, while at the same time addressing the "external" goal of a sustainable current account. In theory, long-standing capital account restrictions could help a country achieve this external goal by enabling its government to manage its real exchange rate (Jeanne 2011). Episodic controls on capital inflows could, theoretically, enable monetary authorities to fight inflation by raising interest rates without simultaneously facing the appreciation of the currency that would then occur with unrestricted capital flows.

Episodic capital controls could also confer benefits through another means, by promoting financial stability. The recent global crisis began in the financial markets, and financial markets were a key vector through which economic distress spread from one country to another. This experience has highlighted some general questions about financial market policies, including the potential role for prudential capital controls. Capital controls may be a viable alternative to other prudential policies, such as bank regulation and supervision, in an economy that lacks resources to undertake these policies (provided it does have the resources to enforce capital controls). Also, capital controls can be more broad-based than bank regulation, an important consideration in economies in which capital flows in through channels other than regulated financial institutions (Ostry and others 2011b). ${ }^{6}$

5. A risk premium could drive a wedge between expected returns, and in theory, the equalization of expected returns could be achieved through the possibility of capital flows rather than actual flows. Shambaugh (2004) provides evidence supporting the empirical relevance of the policy trilemma.

6. There is overlap between policies that could be construed as capital controls and those that may be considered macroprudential regulations, as discussed in detail in Ostry and others (2011a). For example, higher bank reserve requirements for accounts held by nonresidents than for those held by residents is both a capital control (because it treats residents and nonresidents differently) and a macroprudential policy (because it seeks to foster financial stability through regulating the banking sector). This policy is more finely gauged than a general reserve requirement and may accurately reflect the greater predilection for nonresidents to engage in a bank run. In practice, there could be political reasons for distinguishing between macroprudential policies, which could be justified for promoting financial stability, and capital controls, which may be decried as interfering in the operation of international asset markets. 
Recent theoretical research (surveyed by Korinek 2011) has considered how episodic capital controls could contribute to financial stability and prevent boom-bust cycles. The starting point for this work is the recognition that a possible response to certain inherent characteristics of financial markets, such as asymmetric information, is the introduction of constraints, such as collateral requirements, that limit borrowing, but that asset price booms and currency appreciations can weaken these constraints and contribute to increased borrowing, for example by raising the value of assets used as collateral. A subsequent collapse in asset prices, or currency depreciation, can then have cascading effects as the negative feedback loop of a decline in collateral value, a reduction in loans, a decrease in aggregate demand, and a further decline in asset prices and collateral value plays out. Anton Korinek (2011) discusses how increased borrowing by individuals raises asset values and loosens collateral constraints, thereby collectively contributing to financial fragility, and compares this with the familiar externality that arises when drivers do not consider their contribution to air pollution. ${ }^{7}$ Just as a tax on gasoline could force drivers to internalize the pollution externality, so a tax on capital inflows could be employed to limit foreign borrowing and make the financial system more resilient.

This theoretical work emphasizes that the optimal controls on capital inflows would be episodic and, more precisely, procyclical, strengthening as inflows increased and loosening as they ebbed. In addition, the optimal controls would not be broad based, but would target inflows that present particular concerns about financial vulnerability, such as foreign currencydenominated debt as opposed to direct investment. ${ }^{8}$ But the size of the optimal inflows "tax" suggested by model calibrations is typically quite small. Korinek (2010), using data from Indonesia, calculates an optimal tax of 0.44 percent on rupiah-denominated debt and 1.54 percent on dollar debt. Javier Bianchi and Enrique Mendoza (2010) calibrate a model using U.S. data and find an optimal prudential tax on debt of about 1 percent. Bianchi (2011), using Argentine data, calculates an average optimal state-contingent tax on debt of 5 percent and, alternatively, an optimal fixed tax on debt of 3.6 percent. ${ }^{9}$

7. The market failure in this case arises because of imperfections in financial markets due to features such as asymmetric information.

8. Consideration of the relative riskiness of assets gives rise to a "pecking order" of capital controls (Ostry and others 2010). I consider below whether controls have been imposed in a manner consistent with this pecking order.

9. In these models the welfare implications of imposing an optimal tax on capital inflows are also quite small. For example, Bianchi (2011) estimates the welfare gains from correcting the externality associated with overborrowing at 0.135 percent of permanent consumption. This parallels the tiny welfare gains found in models that attempt to assess the costs of business cycles. 
A tax in this range might be considered inconsequential by investors at a time of rapid appreciation or a vibrant boom that substantially raises returns in the affected markets, and therefore the magnitude of these calculated taxes may very well be too small to stem inflows during periods when they are most needed.

\section{I.B. Capital Controls in Practice: A Brief History}

Interest in imposing capital controls tends to emerge, naturally enough, when events call into question the desirability of unfettered capital movements. Capital moved freely across national borders during the pre-World War I gold standard period, a time when, as John Maynard Keynes (1920, pp. 11-12) famously put it, "The inhabitant of London could order by telephone, sipping his morning tea in bed, the various products of the whole earth ... he could at the same moment and by the same means adventure his wealth in the natural resources and new enterprises of any quarter of the world." About a dozen years after he penned these words, however, during the depths of the Great Depression, Keynes's focus turned toward the instability arising from volatile capital flows. In a 1933 speech in Dublin (quoted in Skidelsky 1992, p. 477), he stated, "I sympathize ... with those who would minimize rather than those who would maximize economic entanglements among nations. Ideas, knowledge, art, hospitality, travelthese are things which should of their nature be international. But let goods be home-spun whenever it is reasonable and conveniently possible and, above all, let finance be national." These suspicions of international capital movements contributed to the prevalence of administrative capital controls under the Bretton Woods international monetary system after World War II.

The Bretton Woods system broke apart in the early 1970s and was replaced by a nonsystem of generalized floating exchange rates. Administrative capital controls in the richer countries began to be relaxed around that time as well. The prospect of international capital movements leading to wild swings in currency values led James Tobin to propose, in 1972, a market-based capital control in the form of a small tax on transactions in foreign exchange, to "throw some sand in the wheels of our excessively efficient international money markets," as he put it later (Tobin 1978, p. 154). Although never enacted, the Tobin tax on currency transactions remains a touchstone for those who advocate limiting capital flows, and discussion about it reemerges at times of concern about international capital movements.

These concerns were, for the most part, relatively dormant during the first half of the 1990s. At that time of widespread economic prosperity, 
the emphasis was on the role of financial markets in fostering development and growth, and on the view that capital inflows could promote financial development. The newly coined term "emerging markets" reflected the promise of that era. Emerging market economies tended to liberalize restrictions on their capital inflows. A notable exception was the Chilean encaje, a policy enacted in 1991 that required anyone borrowing from abroad to deposit between 20 and 30 percent of the loan at the central bank in a non-interest-bearing account, subject to a 3 percent penalty for early withdrawal. But the encaje was removed in May 1998, and by the end of the century the prevailing mood internationally was one of optimism about inflows to emerging market economies. ${ }^{10}$

This sanguine view of capital flows began to shift in the early 2000s, partly prompted by appreciations of a number of emerging market currencies. These concerns intensified with the advent of the global crisis and the subsequent "currency war" as monetary policy in the developed economies was eased to combat the Great Recession. Many countries tightened their controls or introduced new ones in 2010: besides the intensification of the Brazilian IOF, South Korea tightened limits on foreign banks' holdings of currency derivatives in June, Peru increased banks' reserve requirements for foreign borrowing in August, and in October, Thailand reintroduced a 15 percent withholding tax on interest payments and capital gains on bonds held by foreign investors.

This short history of capital controls over the past 40 years is reflected in the data presented in figure 1, which are based on the indicators of capital controls first developed by Dennis Quinn (1997) and recently updated to include data through 2007 by Quinn, Martin Schindler, and Maria Toyoda (2011). Quinn used the broad on/off information on countries' controls in the summary tables in the pre-1996 volumes of the IMF's Annual Report on Exchange Arrangements and Exchange Restrictions (AREAER), supplemented by descriptions of the controls in an effort to capture their intensity, to create indicators for two categories of controls on capital transactions, those by residents and those by nonresidents. Each indicator ranges from zero to 2, and their sum results in an overall indicator that ranges from zero to 4 , with larger values indicating weaker

10. Another notable experience in the 1990s was Malaysia's imposition of controls on outflows in September 1998, at the time of the Asian financial crisis, that effectively outlawed the transfer of ringgit abroad. 
Figure 1. Capital Controls in Developed and Emerging Market Economies, 1970-2007

Inverse Quinn index ${ }^{\mathrm{a}}$

(4 = strongest controls)

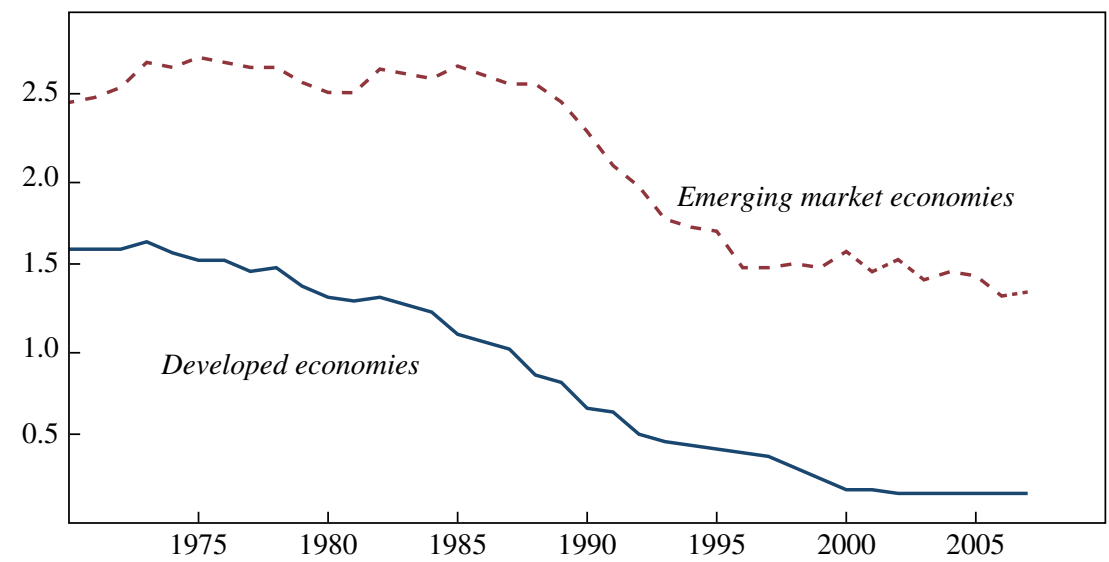

Source: Quinn, Schindler, and Toyoda (2011).

a. The index is a broad measure of the incidence and strength of capital controls, redefined here such that higher values indicate stricter controls. See the text for further details. Data are unweighted averages for the 23 developed and 21 emerging market economies listed in table 2.

restrictions. ${ }^{11}$ The updated Quinn, Schindler, and Toyoda (2011) series conforms to this template. Figure 1 inverts the series such that zero represents the absence of restrictions and 4 the most stringent restrictions.

Figure 1 presents the annual averages of this inverse Quinn index for 23 developed economies and for 21 emerging market economies (listed in table 2 below) for the period 1970-2007. These series show that, on average, the developed economies steadily reduced their capital controls from the mid-1970s through the turn of the century and kept them at that relatively low level through 2007. In contrast, the emerging market economies, on average, did not see a marked reduction of capital controls until the late 1980s; a trend toward capital account liberalization then followed, which stalled in the late 1990s. ${ }^{12}$ By this indicator the capital

11. The original Quinn scoring method, for both categories (transactions by residents and transactions by nonresidents) is as follows: zero means payments are forbidden, 0.5 means that quantitative or other regulatory restrictions are imposed, 1 means that transactions are subject to heavy taxes, 1.5 means that there are less severe taxes, and 2 means that transactions are free of restrictions or taxes.

12. It was this trend toward liberalization until the mid-1990s that tended to focus empirical research using the pre-1996 AREAER classification on the effects of capital account liberalization. 
accounts of these 21 countries were about as open in 2007 as they had been a decade earlier.

\section{I.C. Controls on Capital Inflows by Asset Category, 1995-2010}

The data used to construct the indicators presented in figure 1 give a sense of the overall stance of policy but do not distinguish between inflows and outflows, nor do they offer information on restrictions on separate categories of assets. Beginning with the 1996 issue (which reports on conditions in 1995), the AREAER provides this greater detail. Schindler used the new AREAER format to develop new indicators for both inflow and outflow controls covering six asset categories; Schindler (2009) presents data on these indicators for 1995-2005. The six categories are not an exhaustive list of asset types but do cover the "lion's share of global cross-asset holdings . . that broadly reflects the structure of global de facto financial integration" (Schindler 2009, p. 226). This paper adopts Schindler's method and updates his data set to include the period 2006-10. For each of the inflow categories, for each country and year, the indicator takes a value of zero if the country has no controls in place and 1 if otherwise. ${ }^{13}$

The six categories and their definitions are presented in table 1 . The first two categories, "money market instruments" and "bonds," refer to controls on debt instruments; the former covers assets with an original maturity of 1 year or less and the latter (data for which are available only from 1997 to 2010) those of longer maturity. The "financial credits" category refers to controls on banks. The next two categories represent controls on shares, either of individual companies ("equities") or of mutual funds or other investment trusts ("collective investments"). The sixth category, "direct investment," refers to controls on investments that involve active participation in the management of the acquired entities. Figure 2 shows the proportions of country-year observations with capital controls across these six categories of assets. There is a marked similarity in the incidence of these controls across categories, which ranges between 30 percent (for financial credits and collective investments) and 37 percent (for money market instruments).

Figure 2 does not, however, capture the variation in the prevalence of controls across groups of countries or across time. Figure 3 presents

13. Schindler distinguishes between cases involving controls on either nonresidents or residents but not both, and cases involving controls on transactions by both nonresidents and residents. For more details, see Schindler (2009, p. 228 and footnote 10). 
Table 1. Asset Categories

\begin{tabular}{|c|c|}
\hline Category & Definition \\
\hline Money market instruments & $\begin{array}{l}\text { Debt securities with original maturity of } 1 \text { year or less, such } \\
\text { as certificates of deposit and bills of exchange, treasury } \\
\text { bills and other short-term government paper, bankers' } \\
\text { acceptances, commercial paper, interbank deposits, and } \\
\text { repurchase agreements }\end{array}$ \\
\hline Bonds & $\begin{array}{l}\text { Debt securities with original maturity of more than } 1 \text { year, } \\
\text { such as bonds, notes, and debentures }\end{array}$ \\
\hline Financial credits & $\begin{array}{l}\text { Credits other than commercial credits granted by all resi- } \\
\text { dents, including banks, to nonresidents, or vice versa }\end{array}$ \\
\hline Equities & $\begin{array}{l}\text { Shares and other securities of a participating nature if not } \\
\text { purchased for the purpose of acquiring a lasting econom- } \\
\text { ic interest in the management of the issuing enterprise }\end{array}$ \\
\hline Collective investments & $\begin{array}{l}\text { Assets in institutions for collective investment, such as } \\
\text { mutual funds, unit trusts, and investment trusts }\end{array}$ \\
\hline Direct investment & $\begin{array}{l}\text { Assets created for the purpose of establishing a lasting eco- } \\
\text { nomic relationship either abroad by residents or domesti- } \\
\text { cally by nonresidents, essentially for the purpose of produc- } \\
\text { ing goods and services, and in particular, assets that allow } \\
\text { investor participation in the management of the enterprise. } \\
\text { The category includes the creation or extension of a wholly } \\
\text { owned enterprise, subsidiary, or branch and the acquisition } \\
\text { of full or partial ownership of a new or existing enterprise } \\
\text { that results in effective influence over its operations. }\end{array}$ \\
\hline
\end{tabular}

Source: Based on Schindler's (2009) cataloguing of information in the International Monetary Fund's Annual Report on Exchange Arrangements and Exchange Restrictions.

averages of the control indicators in each of the years 1995-2010 for three aggregated categories of assets: debt securities (money market instruments and bonds), portfolio equity and bank credit (financial credits, equities, and collective investments), and direct investments for the same 23 developed economies and 21 emerging market economies as before. The first thing to note is a cross-sectional difference. The averages for the developed economies range from 2 to 26 percent, with both the debt securities category and the portfolio equity and bank credit category lying within a relatively narrow range of 2 to 13 percent, and the direct investment category in a wider and distinctly higher range of 13 to 26 percent. In contrast, the averages for the emerging market economies range from 43 to 71 percent, and the averages for direct investment are lower than those for the other two categories each year.

The averages for both country groups also show notable time-series variation. The developed economies, as a group, saw a reduction in controls on money market instruments and bonds from an annual average of 
Figure 2. Incidence of Capital Controls by Asset Category, 1995-2010

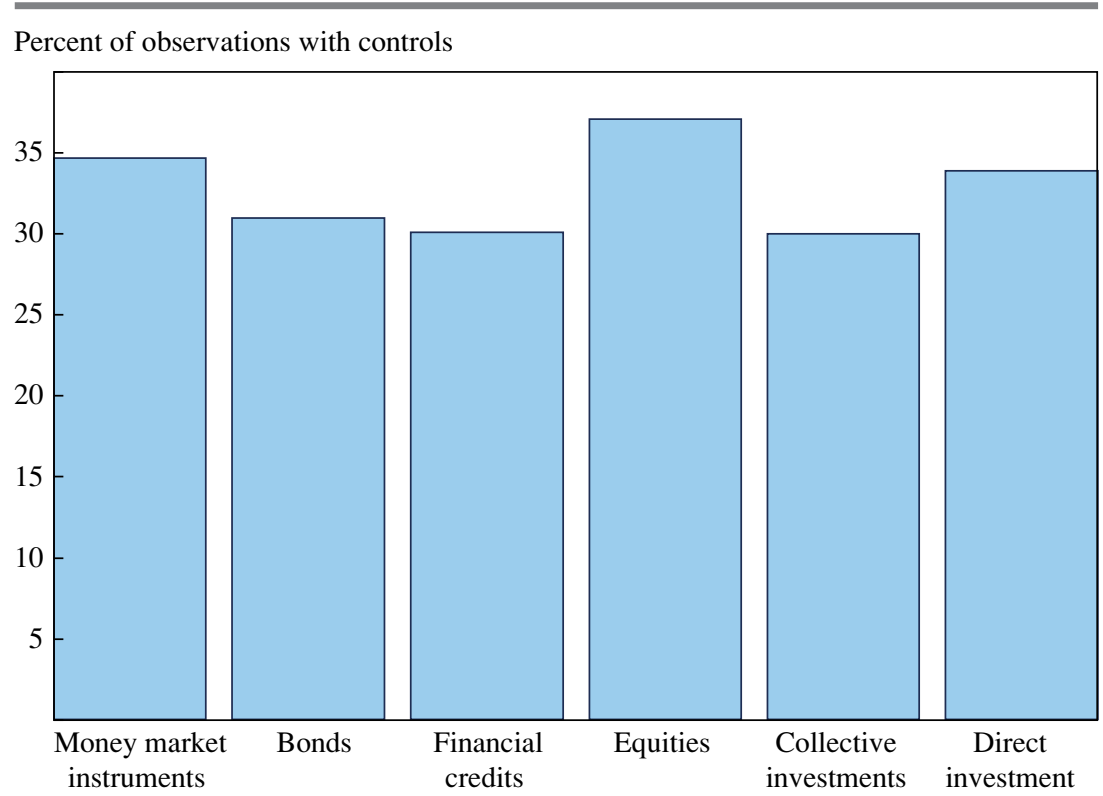

Source: Author's calculations.

a. The figure shows the percentage of all observations in which controls on the indicated asset were in place, where each observation is for one country of the 44 in the sample in one of the years 1995-2010. See table 1 for asset category definitions.

10.9 percent in 1997 to 2.2 percent in 1999 , but then an increase beginning in 2003 that reached 10.9 percent in 2008. The annual average for the direct investment category also began to rise in 2003, from 13 percent, its value since 1999 , to 26 percent in 2006-10. The emerging market economies, like the developed economies, saw a decrease in the annual average for controls on the debt securities category in the first part of the sample period, from 71 percent in 1997 to 52 percent in 2002, and a subsequent increase to 67 percent in 2009. Averages for the direct investment category and the portfolio investment and bank credit category decreased in the mid-2000s to their lowest values in 2004 and 2005, respectively, and subsequently stayed within a relatively narrow range.

For five of the asset categories (all but direct investment), the data on inflow controls by country allow the 44 countries to be divided into three groups (table 2): 16 countries that were persistently (that is, almost always) open to inflows of all five categories, 10 that were persistently closed to inflows of at least four categories, and 18 that had episodic controls- 
Figure 3. Controls on Capital Inflows, by Broad Asset Category, 1995-2010a

Average of countries' indicators

\section{Developed economies}

$(1=$ any controls present $)$

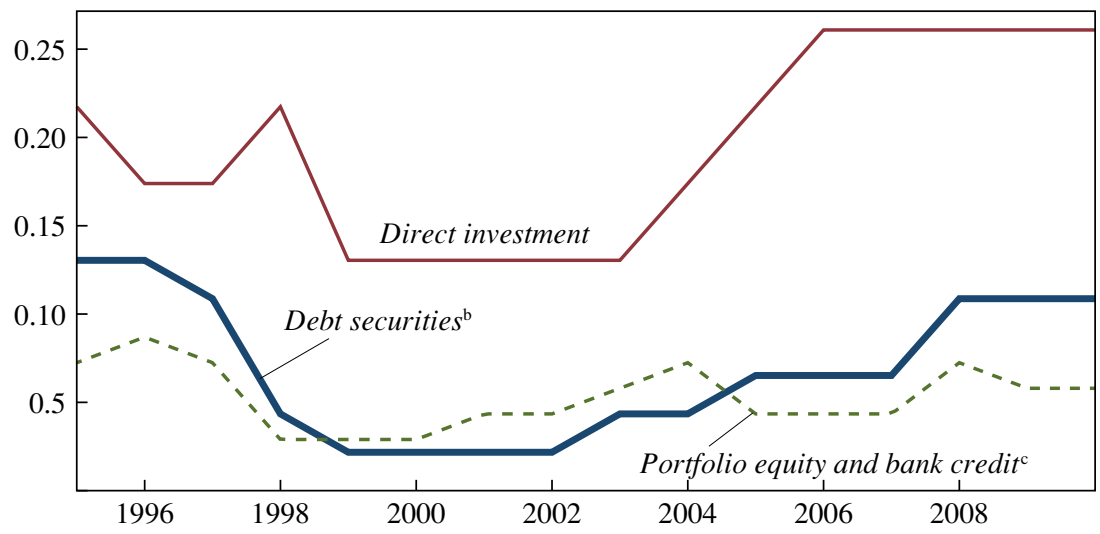

\section{Emerging market economies}

Average of countries' indicators

$(1=$ any controls present $)$

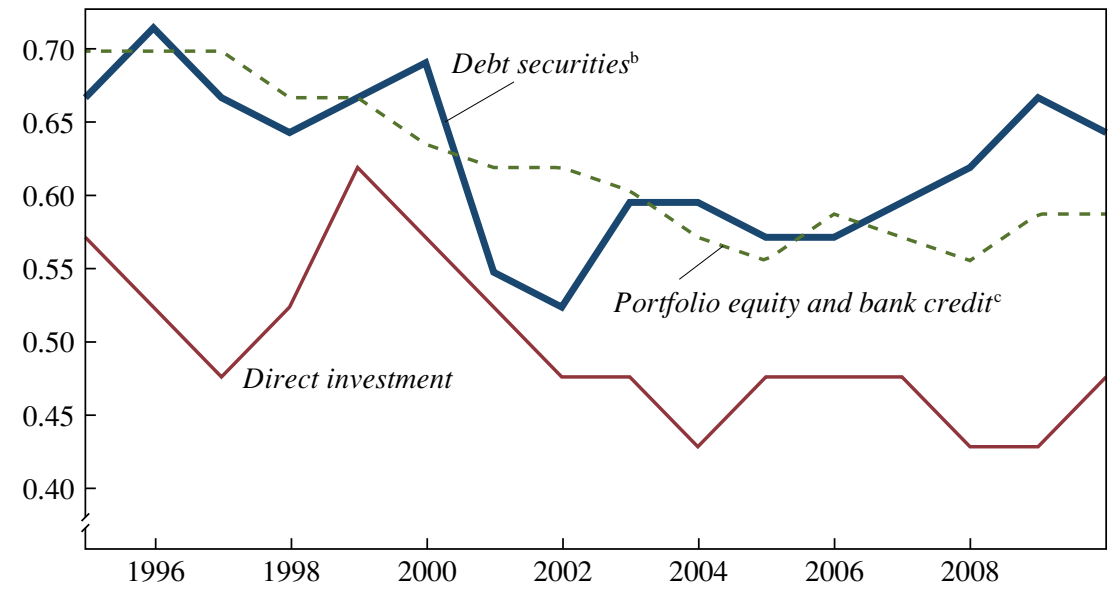

Source: Author's calculations.

a. Data are unweighted averages of the countries in the sample.

b. Combines the categories "money market instruments" and "bonds" (see table 1 for category definitions).

c. Combines the categories "financial credits," "equities," and "collective investments." 
Table 2. Countries in the Sample by Inflow Controls Category for 1995-2010

\begin{tabular}{|c|c|c|c|c|}
\hline \multicolumn{2}{|c|}{ Persistently open (16 countries) } & \multirow{2}{*}{$\begin{array}{c}\text { Persistently } \\
\text { closed } \\
\text { (10 countries, } \\
\text { all emerging } \\
\text { markets) }\end{array}$} & \multicolumn{2}{|c|}{ Episodic $(18 \text { countries })^{\mathrm{a}}$} \\
\hline $\begin{array}{l}\text { Developed } \\
\text { economies }\end{array}$ & $\begin{array}{c}\text { Emerging } \\
\text { market } \\
\text { economies }\end{array}$ & & $\begin{array}{l}\text { Developed } \\
\text { economies }\end{array}$ & $\begin{array}{c}\text { Emerging } \\
\text { market } \\
\text { economies }\end{array}$ \\
\hline $\begin{array}{l}\text { Austria } \\
\text { Belgium } \\
\text { Canada } \\
\text { Denmark } \\
\text { Finland } \\
\text { Greece } \\
\text { Italy } \\
\text { Japan } \\
\text { Netherlands } \\
\text { New Zealand } \\
\text { Norway } \\
\text { Spain } \\
\text { Switzerland } \\
\text { United Kingdom } \\
\text { United States }\end{array}$ & Egypt & $\begin{array}{l}\text { China } \\
\text { Colombia } \\
\text { India } \\
\text { Indonesia } \\
\text { Malaysia } \\
\text { Morocco } \\
\text { Philippines } \\
\text { Russia } \\
\text { South Africa } \\
\text { Thailand }\end{array}$ & $\begin{array}{l}\text { Australia (1) } \\
\text { France } \\
\text { Germany } \\
\text { Iceland (4) } \\
\text { Ireland (1) } \\
\text { Israel } \\
\text { Portugal (2) } \\
\text { Sweden (1) }\end{array}$ & $\begin{array}{l}\text { Argentina (3) } \\
\text { Brazil (3) } \\
\text { Chile } \\
\text { Czech Rep. (2) } \\
\text { Hungary } \\
\text { Korea } \\
\text { Mexico (2) } \\
\text { Peru (1) } \\
\text { Poland (1) } \\
\text { Turkey (2) }\end{array}$ \\
\hline
\end{tabular}

Source: Author's categorization based on International Monetary Fund, Annual Report on Exchange Arrangements and Exchange Restrictions, 1996-2011.

a. Numbers in parentheses indicate the number of different years between 1995 and 2010 that the country imposed controls. Where no number is given, the country removed existing controls during the sample period but did not impose new controls.

these countries had some experience with capital controls but were not persistently closed to inflows across a wide range of categories. ${ }^{14}$ Of these 18 countries, 12 imposed controls at some point between 1995 and 2010. For these, table 2 reports the number of years during which controls were imposed ( 23 country-years in all); the other 6 began the sample period with some controls in place but removed some or all of them during the period.

Table 3 shows the annual geometric average of income per capita (in 2005 dollars at constant purchasing power parity) over 1995-2010 for the countries in each of the three groups. The average in the persistently closed group, at $\$ 4,902$, was 18 percent of that of the persistently open countries, and 28 percent of that of the episodic group. All the countries in the

14. The analysis below does not consider controls on direct investment inflows because these controls are typically imposed for reasons such as national security rather than to achieve short-run macroeconomic targets or promote financial stability. Table A.1 in the appendix presents a comprehensive listing of the countries' experience with controls on capital inflows across all six categories of assets. 
Table 3. Summary Statistics for the Countries in the Sample, 1995-2010

\begin{tabular}{lccc}
\hline & \multicolumn{3}{c}{ Inflow controls category } \\
\cline { 2 - 4 } & $\begin{array}{c}\text { Persistently } \\
\text { open }\end{array}$ & $\begin{array}{c}\text { Persistently } \\
\text { closed }\end{array}$ & Episodic \\
\hline Average GDP per capita & $\$ 27,054$ & $\$ 4,902$ & $\$ 17,387$ \\
$\begin{array}{l}\text { Total country-year observations } \\
\text { Observations with controls on any } \\
\quad \text { category }\end{array}$ & 256 & 160 & 288 \\
$\begin{array}{l}\text { Observations with controls on all } \\
\text { categories }\end{array}$ & $0(0 \%)$ & $160(100 \%)$ & $157(55 \%)$ \\
$\begin{array}{l}\text { Observations with controls on } \\
\text { either } 4 \text { or 5 categories }\end{array}$ & $0(0 \%)$ & $111(69 \%)$ & $26(9 \%)$ \\
\hline
\end{tabular}

Source: Author's calculations.

a. See table 2 for a listing of the countries in each category.

b. Unweighted geometric average of all countries in the category over all years, in 2005 purchasing power parity-adjusted dollars.

c. Observations of direct investment controls are excluded.

persistently closed group are emerging market economies, whereas all but one (Egypt) in the persistently open group are developed economies. ${ }^{15}$ Further distinctions across these three groups, with respect to the incidence of their use of capital controls, are presented in the last three rows of table 3. The first row shows that there were no instances of controls on any of the five categories of assets in any year for any of the countries in the persistently open category; in contrast, 55 percent (157 of 288) of the observations in the episodic category had restrictions on at least one category of assets, and, as would be expected, every country in the closed category had restrictions on at least one category of assets in each year. The statistics in the next row further demonstrate the difference in the incidence of controls for countries in the episodic and persistently closed categories. There were controls on all five categories of assets in 69 percent of the observations for the 10 countries in the persistently closed category, but in only 9 percent of the observations for the 18 countries in the episodic category. This difference is even more marked when one considers the number of observations involving controls on at least four categories of assets: this condition was met by only 15 percent of the observations for countries in the episodic category but by 93 percent of the observations for countries in the persistently closed category. Thus, walls to capital inflows for this latter group were both persistent and wide.

15. This fact will be important in the next section, which considers the partial correlations of capital controls with aggregate economic variables. 


\section{I.D. The Pecking Order of the Imposition of Controls on Capital Inflows}

I close this section by looking at the pattern of imposition of controls across asset categories. The theory of the prudential role of capital controls described above prescribes a "pecking order," with controls imposed first on those assets most likely to contribute to financial instability. A practical application of this principle is found in Jonathan Ostry and others (2010), who propose a pecking order in which controls are imposed first on foreign currency debt, then on inflation-indexed local currency debt, then on unindexed local currency debt, then on portfolio equity investment, and finally on direct investment. The categories in the AREAER do not allow for so finely grained an analysis, but one can still analyze whether the pattern of the imposition of controls is consistent with financial stability considerations.

The six categories of assets in table 1 are ordered by decreasing contribution to the risk of financial instability: short-maturity money market instruments pose more risk to financial stability than longer-maturity bonds, bonds more risk than bank lending, bank lending more risk than equity flows and collective investments, and direct investment the least risk of all. This ordering suggests two alternative patterns of the imposition of controls consistent with the prescribed pecking order: in the first, controls on the first two categories should precede the imposition of controls on the others (and there were no controls already in place on any of these three categories); in the second, a simultaneous imposition of controls on bank lending and either category of debt securities should precede their imposition on equity flows or collective investments. These are relatively weak pecking order conditions and tilt toward the finding of a pecking order. ${ }^{16}$

Even under these relatively weak conditions, however, there is little evidence that capital controls were imposed in a manner consistent with this pecking order. Table 2 showed that there were 23 episodes of newly imposed controls for the subset of 12 countries that imposed controls episodically between 1995 and 2010. In 7 of these 23 episodes, controls were

16. There are five ways in which these conditions make it more likely to find a pattern consistent with the pecking order: first, there is no requirement that controls on money market instruments precede those on bonds; second, controls on both categories of debt securities are treated interchangeably; third, controls are required on only one of the two categories of debt securities; fourth, controls can be imposed simultaneously (or, more precisely, within a single calendar year) on at least one debt securities category and the financial credits category; and finally, direct investment is not considered since the imposition of controls on this category of assets before the imposition on any other category would lead to a finding that the pecking order was not met. 
imposed on either money market instruments or bonds (or both), but in only 4 were these controls imposed in the absence of controls on financial credits, equities, or collective investments. In three of these four casesTurkey in 2007, and Ireland and Peru in 2008 - controls were imposed on money market instruments, but not on bonds. The fourth case would not qualify under a stronger form of the pecking order: Iceland imposed controls on bonds in 2005, but not on money market instruments. A fifth case consistent with the pecking order is that of Argentina in 2003, when controls were imposed on money market instruments, bonds, and financial credits. Thus, only 5 of the 23 cases of the imposition of controls on capital inflows were consistent with these weak pecking order conditions, providing little evidence that governments have systematically acted in a manner consistent with the prescriptions of prudential capital controls theory.

Of course, governments may have reasons for imposing capital controls other than to promote financial stability. In particular, they may be concerned about the competitiveness effects of a currency appreciation. In this case the pattern of imposition could reflect an effort to use those episodic controls that are the most efficacious and least likely to be evaded. But whether or not capital controls achieve their desired results is an open question. The next section considers the correlation of exchange rates, as well as other aggregate variables, with both episodic and long-standing capital controls.

\section{Capital Controls and Economic Outcomes}

Interest in the use of capital controls has grown in the wake of the Great Recession, as it was perceived that economies that blocked capital inflows performed better during the recession than those that did not. ${ }^{17}$ The theory discussed in section I provides a rationale for this view, which is also supported by statistics showing that countries with capital controls had higher rates of GDP growth and lower rates of growth of financial variables associated with asset price booms. In a similar fashion, the value of capital controls is supported by the view that countries with long-standing

17. Some argue that countries like China and India, which had long-standing controls in place, were spared the financial upheavals that roiled more open economies, as mentioned in Ostry and others (2010). In contrast, Kose and others (2009, p. 27) write, "Capital account liberalization is believed to have played an important role in fomenting financial crises and has been indicted by some observers as the proximate cause for the crises experienced by emerging markets in recent decades. But there is little empirical evidence to support the view that capital account liberalization by itself increases vulnerabilities to crises." 
controls, like China, can successfully stem upward pressure on their currencies.

The empirical results presented in this section provide a preliminary investigation of the correlations between controls on capital inflows and variables associated with financial vulnerabilities, GDP growth, and the real exchange rate. I present unconditional statistics as well as partial correlations drawn from the annual panel data set of 44 countries over the 1995-2010 period. At the end of this section, I also consider the association of capital controls and exchange rates at a monthly frequency. ${ }^{18}$

A key objective in this analysis is to distinguish the effects of longstanding capital controls from those of episodic controls on different categories of assets. The panel analysis makes this distinction with the use of three separate dummy variables: $C L$, which equals 1 for all years for all 10 countries with persistent controls on inflows; $B O M M_{t-1}$, which equals 1 in country-years when there were controls on either money market instruments or bonds in the previous year; and $F E C_{t-1}$, which equals 1 in country-years when there were controls on financial credits, equities, or collective investments in the previous year. ${ }^{19}$

Identifying the effects of controls on capital inflows is challenging. Capital controls are typically not imposed in isolation from other policies. Thus, to the extent that these policies are aimed toward the same objective, partial correlations from regression analysis will overstate the association between capital controls and economic outcomes because of omitted variables. ${ }^{20}$ On the other hand, episodic capital controls may be systematically imposed in response to movements in exchange rates, GDP, or financial variables. When this is the case, partial correlations will understate the effect of capital controls on these variables because of endogeneity. For this reason the dummy variables $B O M M_{t-1}$, and $F E C_{t-1}$ are lagged 1 year in an effort to avoid capturing reverse causality-for example, if a real appreciation prompts the imposition of controls. Regressions were also run in which the episodic control variables represent the contemporaneous probability of the imposition of controls derived from probit regressions that

18. Although an analysis at an annual frequency may be less likely to discern significant associations between capital inflows and aggregate economic variables than one using monthly data, it might have more relevance for macroeconomic and financial policy.

19. The fact that $C L$ equals 1 in all years for the 10 countries with persistent controls on inflows means that the panel estimates cannot control for country fixed effects. Year fixed effects are included.

20. Habermeier, Kokenyne, and Baba (2011) argue that controls on inflows are almost always imposed at the same time as other prudential policies. 
use only lagged variables. The results from estimates using this two-stage procedure are almost identical to the ordinary least squares estimates in terms of the pattern of significance. ${ }^{21}$

Statistics presented below show that countries with persistent controls on capital inflows tended to have higher rates of GDP growth and lower rates of growth of financial variables than the other countries in the sample. However, regressions controlling for other variables show that these statistics should not be used as a guide to the efficacy of episodic controls, because, with a few exceptions, there is not a comparable significant partial correlation between episodic controls and economic aggregates, and in many cases the partial correlations for long-standing and episodic controls differ significantly. Countries with long-standing controls differ from other countries in a number of ways, including, as table 2 showed, having lower income per capita. The significant association between long-standing controls and annual growth in aggregate economic variables disappears once one controls for income per capita, and the inclusion of this variable does not shift the estimates toward finding a statistically significant effect of episodic controls.

These results are important from a practical perspective. Policy discussion on the desirability of capital controls is about episodic controls, because these can be imposed and removed as conditions change. The motivation for imposing episodic controls, however, is often drawn from the experience of countries with long-standing controls. Analyses that do not distinguish between episodic and long-standing controls may not provide accurate guidance for decisions about policy on controls on capital inflows. Furthermore, as just noted, the significant estimated link between long-standing controls and aggregate variables does not survive the inclusion of income per capita in the regressions. Finally, although the estimates presented below show a significant real depreciation for China's currency against the dollar compared with countries with open capital accounts, conditional on other factors, this is not the case for the other countries with long-standing capital controls.

21. The estimates of the contemporaneous probability of the presence of controls from these first-stage estimates, $\widehat{B O M M}_{t}$ and $\widehat{F E C}_{t}$, are from probit regressions run for the subset of 18 countries that had experience with episodic inflow controls. The regressors include a dummy variable indicating whether controls were in place the previous year as well as lagged values of GDP growth, the change in the real exchange rate against the dollar, lagged growth in the credit-to-GDP ratio, lagged growth in the debt share, and lagged GDP per capita. The first-stage progit regressions have pseudo- $R^{2} \mathrm{~S}$ of 0.59 for $B O M M$ and 0.65 for $F E C$. The estimates of $\overline{B O M M}_{t}$ and $\widehat{F E C}_{t}$, along with $C L$, were used in regressions that were otherwise identical to the ordinary least squares estimates presented in tables 4,5 , and 6 . 


\section{II.A. Capital Controls and Financial Vulnerabilities}

Events of the past few years have highlighted the role that financial vulnerabilities can play in contributing to economic distress. As discussed above, theory suggests that appropriately imposed episodic capital controls can temper a boom-bust cycle. This section presents a panel analysis of the association between both long-standing and episodic controls on the change in the levels of these variables, as well as on surges of capital inflows. ${ }^{22}$

The results presented in this section are related to those presented by Ostry and others (2012). That paper includes both panel and crosssectional analysis of the effects of capital controls on the share of a country's debt liabilities in total liabilities, the change in private credit relative to GDP, the share of foreign exchange-denominated credit in total credit, and the differences in GDP growth rates before and after the crisis, and their sample includes 51 emerging market economies over the period 1995-2008. Estimates in that paper also control for the presence of domestic prudential regulation. The analysis here is also related to that of Kristin Forbes and Francis Warnock (forthcoming), who find that controls on inflows do not significantly affect surges of gross capital inflows. But neither of these two papers distinguishes between episodic and longstanding capital controls.

The three financial variables studied in this section are the change in private credit relative to GDP, the change in the share of domestic credit provided by the banking sector, and the change in the share of debt liabilities in total liabilities. ${ }^{23}$ Positive growth in each of these variables indicates greater potential for an asset market boom. Also reported is a panel estimate of the partial correlation between capital controls and a qualitative indicator of whether a country has experienced a surge of capital inflows (this series is from Ghosh and others 2012).

Table 4 presents statistics on these variables, as well as annual panel estimates of the partial correlation between each of them and both longstanding and episodic controls on capital inflows. The statistics in the bottom panel show that countries closed to capital inflows tended to have lower growth rates of credit relative to GDP, of bank credit relative to total credit, and of debt liabilities relative to total liabilities than the other

22. It is worth noting that one person's prudential policy may be another's financial repression, that is, government interference in financial markets in order to direct savings toward politically preferred projects. One argument for capital account liberalization is that it promotes financial development (Klein and Olivei 2008). In turbulent times, however, financial development may go hand in hand with a boom-bust cycle.

23. These data are from the World Bank. See data.worldbank.org/indicator/. 


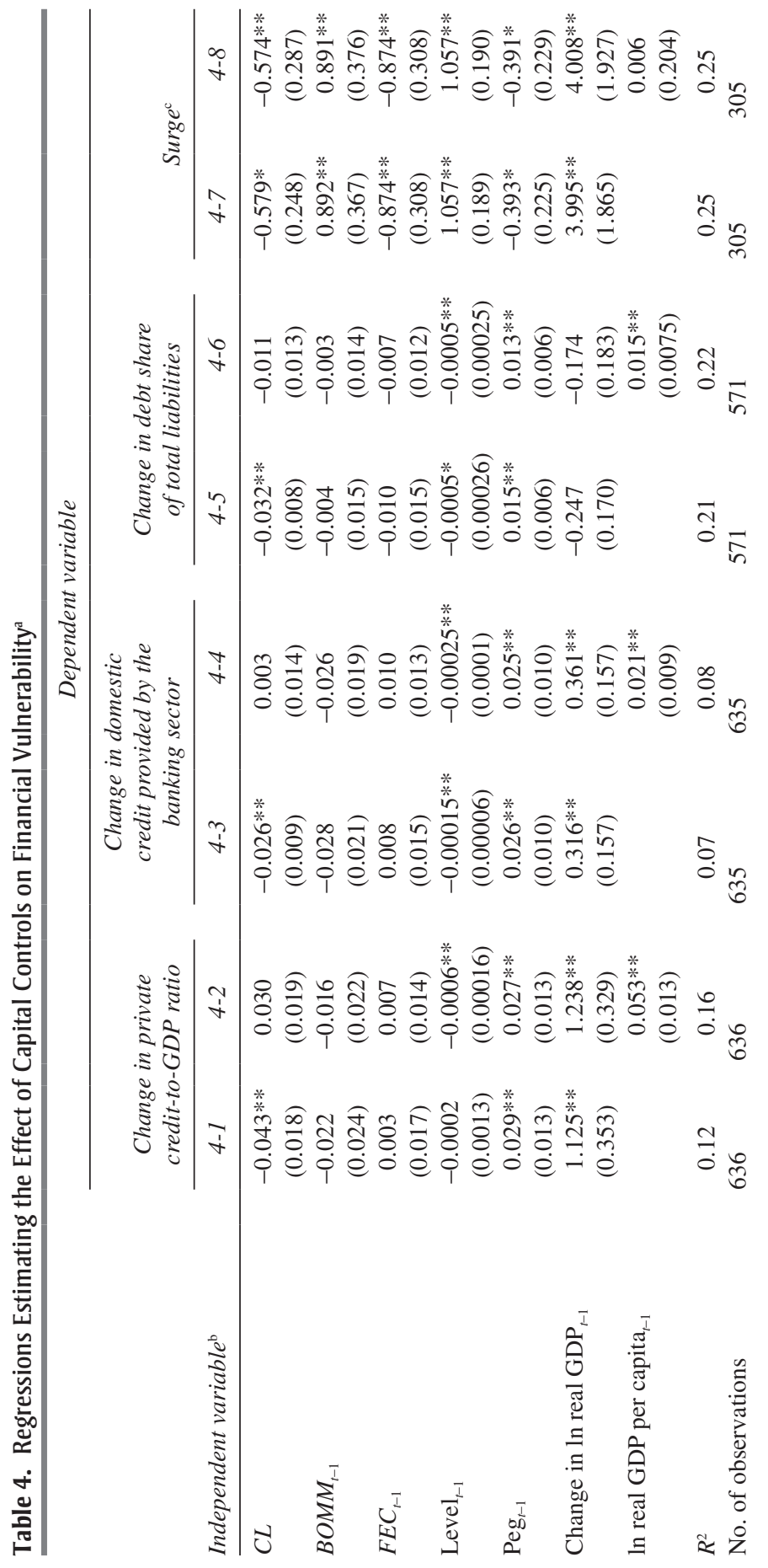




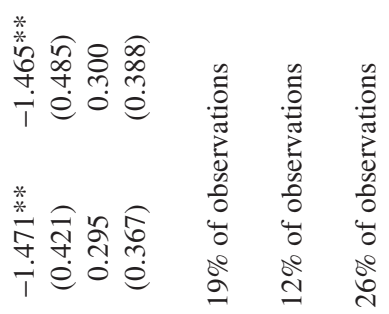

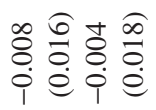

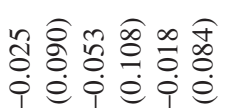

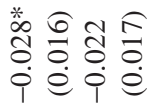

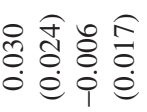

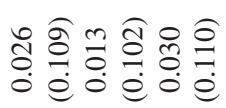

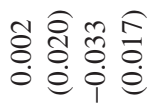

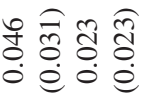

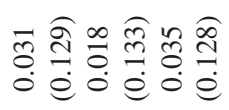

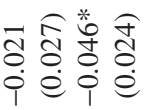

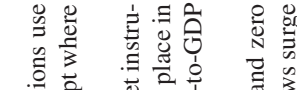

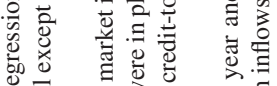

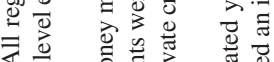

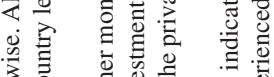

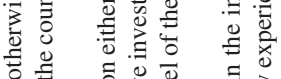

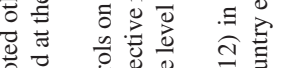

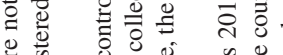

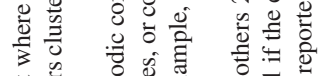

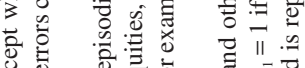

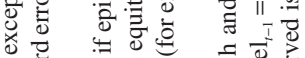

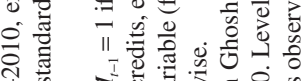

ñ

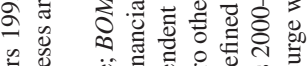

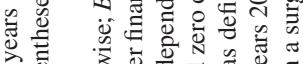

ช 司

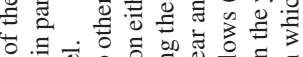

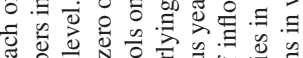

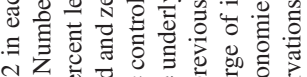

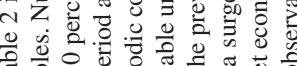

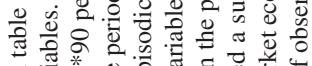

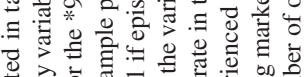

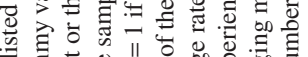

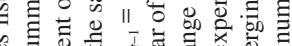

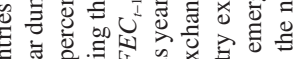

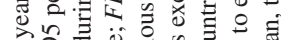

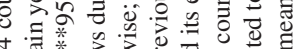

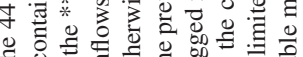

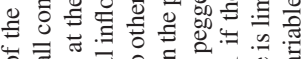

茯

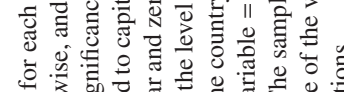

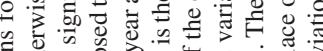

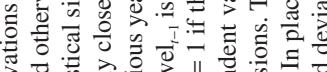

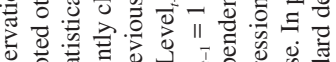

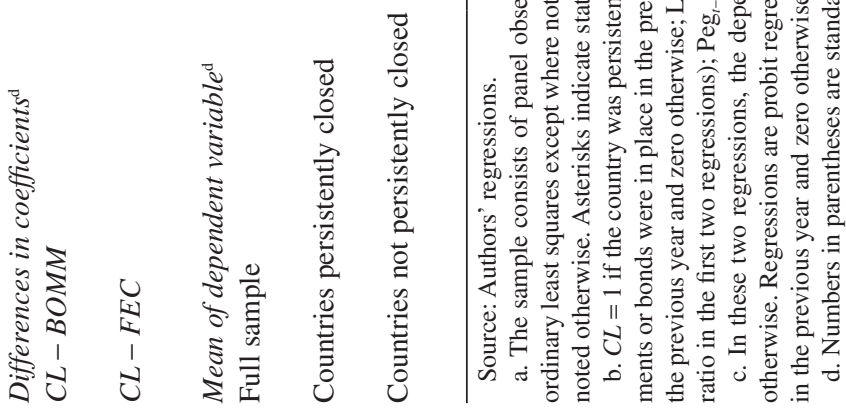

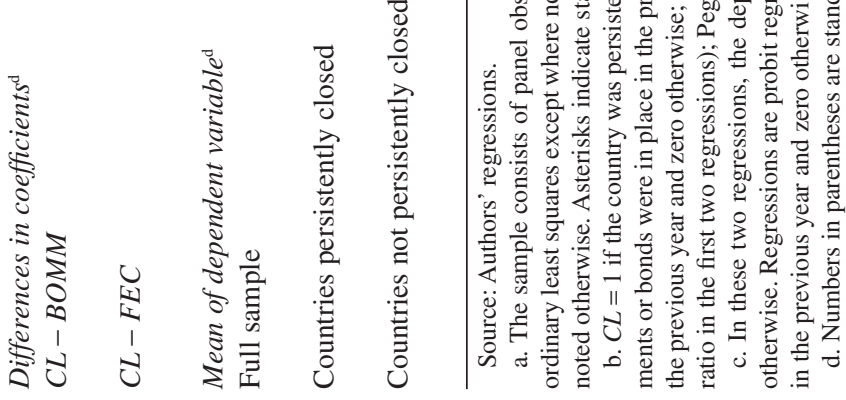


countries in the sample. These 10 countries also had less than half the percentage of observations with a capital inflow surge than the other 34 countries.

The regression estimates in columns 4-1, 4-3, and 4-5 of table 4 show that countries with long-standing controls on capital inflows experienced statistically significantly lower growth rates of the three financial variables, and a significantly lower association with capital inflow surges, than countries with open capital accounts. The same is not true when episodic controls were imposed in the previous period, except that the likelihood of a surge of inflows was lower when controls were imposed on bonds. The partial correlations of episodic controls with the three financial variables are estimated imprecisely (the standard errors almost always exceed the estimated coefficients), and in only two instances is the association significantly lower for long-standing than for episodic controls, as shown in the rows that test for the differences $C L-B O M M$ and $C L-F E C$. But the significant partial correlation of these three financial variables with longstanding controls disappears when lagged real GDP per capita is included as a regressor (columns 4-2, 4-4, and 4-6). The estimates in these columns also show that lagged real GDP per capita consistently enters with a positive and significant coefficient. It is reasonable to interpret the results in columns 4-1 through 4-6 as showing that the significant effect of longstanding controls arises because it serves as a proxy for income per capita.

This is not the case, however, with the estimates of the partial correlation of surges with long-standing and episodic controls (columns 4-7 and 4-8). ${ }^{24}$ Countries with long-standing capital controls had a lower likelihood of an inflows surge, even when controlling for whether there had been a surge in the previous period, for lagged real GDP growth, and for whether the country had pegged its exchange rate in the previous period (year dummy variables are also included in these regressions). The estimates also show a significant negative coefficient on the dummy variable for the presence of controls on financial credits, equities, or collective investments in the previous period. The difference between the estimated coefficient on longstanding controls and that on debt securities $(C L-B O M M)$ is statistically significantly different from zero, and the partial correlation between controls on debt securities and a surge is positive and significant. ${ }^{25}$

24. Because of data limitations, the surge regressions in columns 4-7 and 4-8 include only emerging market economies and cover the period 2001-10.

25. These results also hold for the two-stage estimates described above that employ the instrumented values of $B O M M_{t}$ and $F E C_{t}$. 
Notwithstanding the significant effects for surges, the results in table 3 call into question the effectiveness of capital controls as a prudential measure. Ultimately, however, what is of interest is the relationship between capital controls and these variables because of the potential effect on GDP, a topic that I turn to next. ${ }^{26}$

\section{II.B. Capital Controls and GDP Growth}

As the bottom panel of table 5 shows, the average annual growth rate of real GDP in the 10 countries in the data set with long-standing controls on capital inflows was notably higher than that in the other 34 countries over the period 1995-2010: 4.6 percent versus 2.7 percent. This difference was even larger during the Great Recession period, 2008-10, when the average annual growth rate of the countries with long-standing controls was 4.1 percent, compared with 0.5 percent for the other 34 countries. Of course, these 10 countries differed from the other 34 in many ways other than their stances on capital controls. This section presents evidence on the partial correlations between both long-standing and episodic capital controls and annual GDP growth, to examine whether controls on capital inflows were associated with faster GDP growth when one controls for other factors.

The extensive literature on capital account policies and economic growth has focused on the effects of capital account liberalization. The typical approach is to augment a standard empirical growth model with an indicator of capital controls. Given the available data, these studies did not distinguish between controls on inflows and controls on outflows, or across controls on different types of assets. ${ }^{27}$ In a survey of this literature, Ayhan Kose and coauthors $(2009$, p. 27) write, "Our reading of this large literature based on aggregate data is that it remains difficult to find robust evidence that financial integration systematically increases growth once other determinants of growth are controlled for. Nevertheless, the weight of the evidence seems to be gradually shifting towards finding positive marginal effects."

26. Nevertheless, it is important to consider the effects of capital controls on variables that potentially affect GDP through a boom-bust cycle, and not just the effects on GDP itself, because a sample period may be too short to include the bust part of the cycle.

27. Edison and others (2004) discuss the different types of capital account liberalization indicators employed in their synthesis of the effects of capital account liberalization on economic growth. 


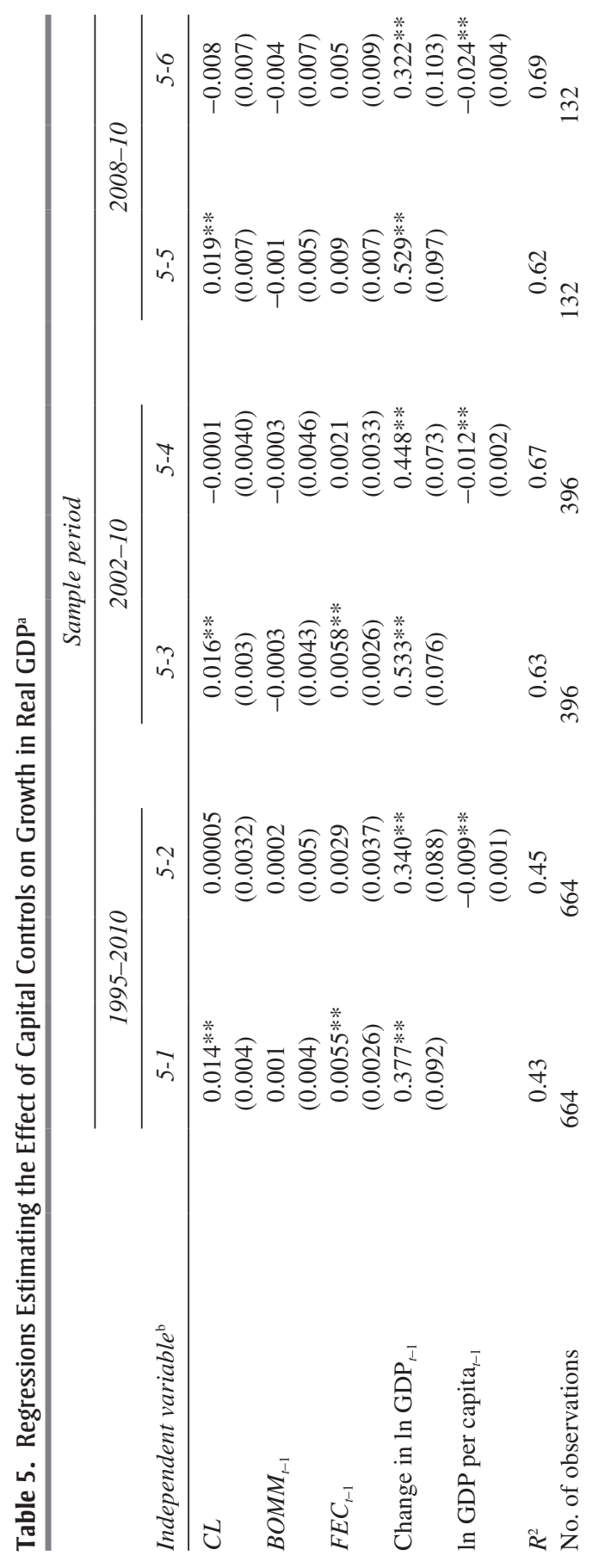




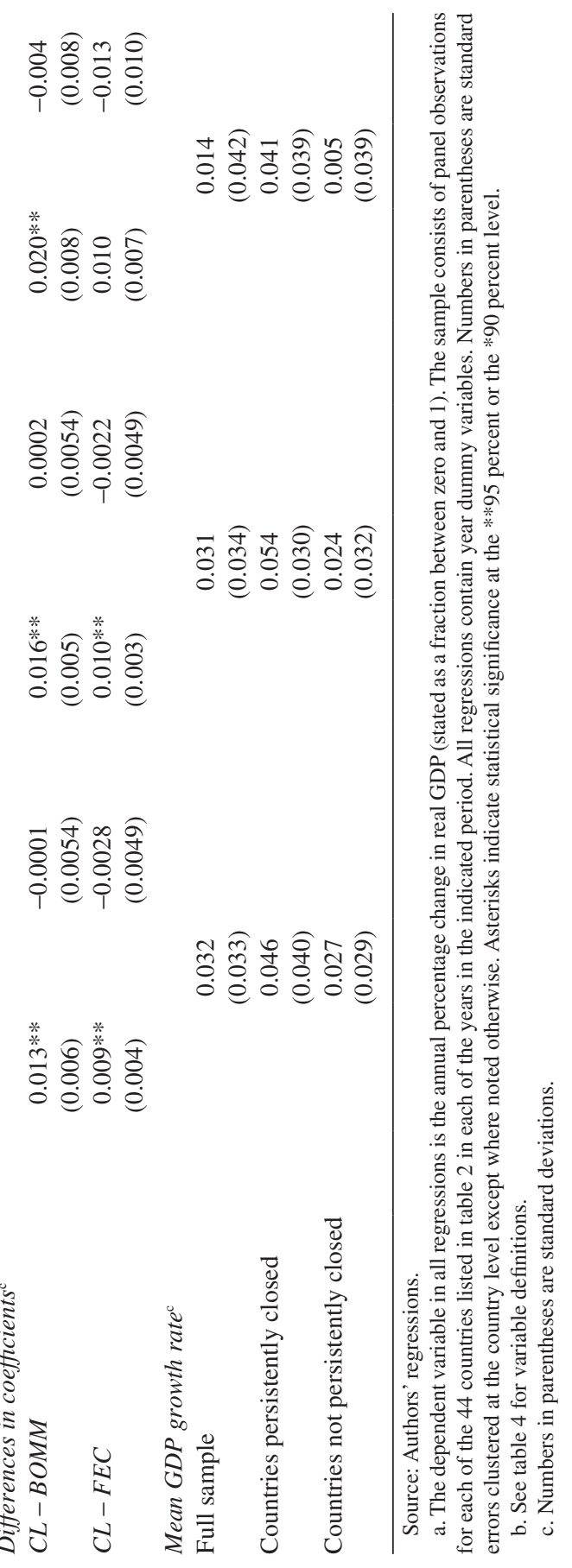


The top panel of table 5 reports panel estimates of the effect of controls on annual real GDP growth for three time periods: 1995-2010, 2002-10, and 2008-10. The odd-numbered columns present estimates, for each of the three time periods, of the partial correlations of GDP growth and the three indicators of controls on capital inflows, controlling for lagged GDP growth and including year fixed effects. These results demonstrate a significant positive partial correlation between long-standing controls on capital inflows and economic growth. The size of the relationship is notable as well, ranging from 1.4 to 1.9 percent per year. A statistically significant difference is also seen between the growth effects of long-standing and of episodic capital controls in most cases. But these results are overturned when lagged income per capita is also included in the regression: the even-numbered columns show no significant partial correlations of real GDP growth with any of the dummy variables representing controls on capital inflows. This is even true for the estimates exclusively focusing on the Great Recession period, when the difference in unconditional growth rates between countries with long-standing controls and the other countries was largest, and a time when capital controls were touted as insulating economies from the economic distress spreading around the world.

\section{II.C. Capital Controls and the Exchange Rate}

As already discussed, the appreciation of many emerging market currencies in the wake of expansionary monetary policy in developed economies during the Great Recession prompted declarations of "currency wars" and the imposition, in several emerging markets, of controls on capital inflows. Were these controls effective in mitigating appreciations? ${ }^{28}$ Did long-standing controls on capital inflows contribute to depreciations, or to lower rates of appreciation than would have otherwise occurred?

This section addresses these questions by considering the partial correlations between controls on capital inflows and the bilateral real dollar

28. Some research on the experience of Chile has shown that its unremunerated reserve requirement (encaje) did not significantly affect the real exchange rate but did have some influence on the composition of inflows, tilting them toward longer maturities. See De Gregorio, Edwards, and Valdés (2000). 
exchange rate of each country. Table 6 presents estimates of these correlations using annual panel data for each of the same three time periods used in table 5. The dependent variable is the change in the real bilateral exchange rate with the dollar, defined such that a positive value indicates a real appreciation of the domestic currency. The regressors include, besides the variables representing controls on capital inflows, the lagged change in the logarithm of the real bilateral dollar exchange rate, a dummy variable for whether the country had a pegged exchange rate, lagged real GDP growth, the logarithm of GDP per capita, and year fixed effects. The estimates in the odd-numbered columns include the same three dummy variables for capital inflow controls used in tables 3 and 4 . The estimates in the even-numbered columns separate the long-standing capital controls variable into a China dummy variable and a not-China dummy variable that equals 1 for observations in which the country is one of the other nine with long-standing controls on capital inflows. This allows an examination of whether China's experience with respect to the bilateral real dollar exchange rate was different from that of the other countries with "walls."

The estimates in columns 6-1 and 6-3 show no significant effects of either long-standing or episodic capital controls. During the crisis period, however, there is evidence that controls on debt securities inflows were associated with a real depreciation of 3.4 percent per year, conditional on the other variables included in the regression. This is equal to about onethird of the standard deviation of the change in the exchange rate during this period. The two-stage procedure described above also produces a significant coefficient on controls on debt securities for this period (not shown in the table), with a value of 0.039 , about 15 percent larger in absolute value than the ordinary least squares (OLS) estimator. None of the other coefficients on episodic controls using the two-stage procedure are significant, a finding consistent with the OLS estimates in table 6. In addition, the estimates in column 6-4 show a significant real depreciation for China in the 2002-10 period, conditional on the other variables included. The coefficient on the China dummy variable is not significant in the other two periods, however.

One concern about these results is that the use of annual data may mask shorter-run exchange rate responses to the imposition of controls on capital inflows. Another means to consider the effect of episodic controls on the exchange rate is to focus on monthly data in the period around the U.S. Federal Reserve's second round of quantitative easing (QE2). Federal Reserve Chairman Ben Bernanke announced QE2 at the 


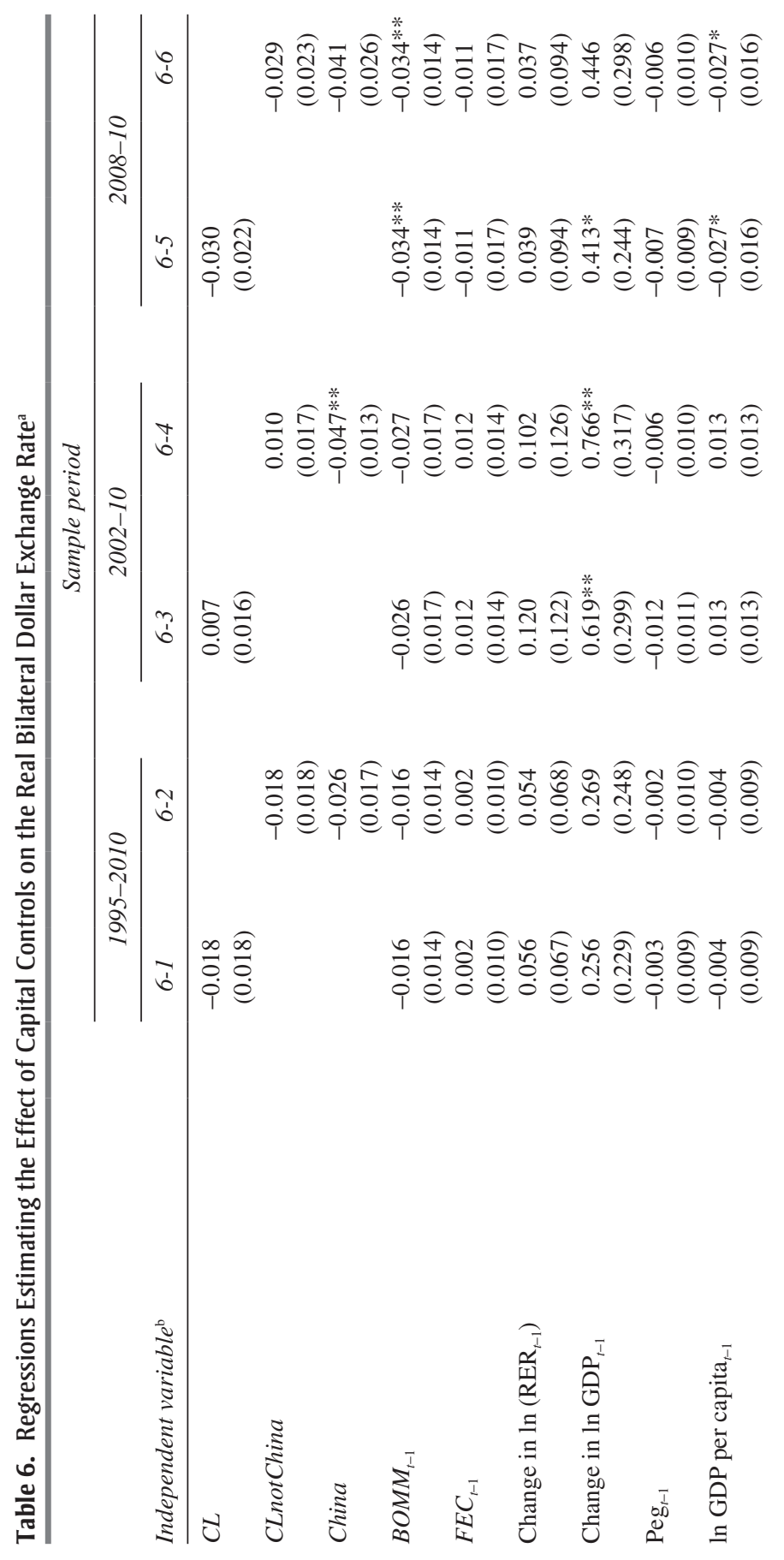




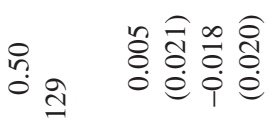

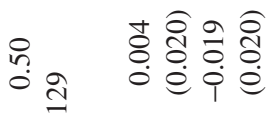

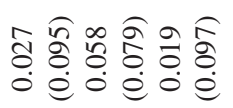

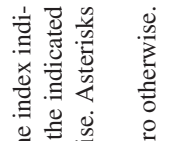

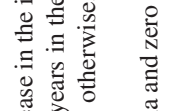

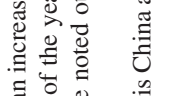

$$
\begin{aligned}
& \text { 壳苛离产 }
\end{aligned}
$$

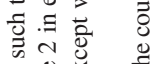

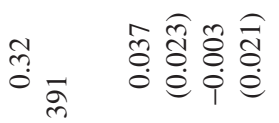

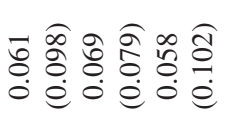

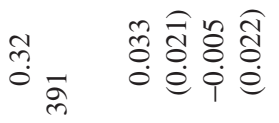

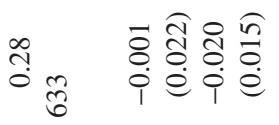

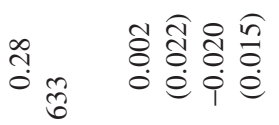

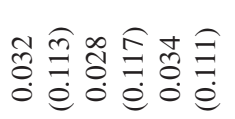

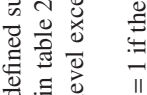

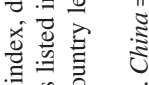

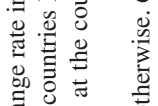

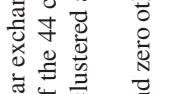

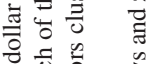

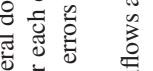

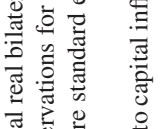

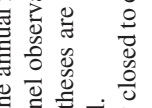

$$
\begin{aligned}
& \text { 㤩焉 } \\
& \text { 品 }
\end{aligned}
$$

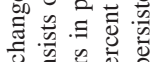

$$
\begin{aligned}
& \infty_{0} \text { है }
\end{aligned}
$$

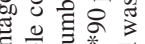

$$
\begin{aligned}
& \text { 过范范 }
\end{aligned}
$$

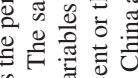

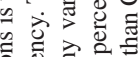

$$
\begin{aligned}
& \text { के }
\end{aligned}
$$

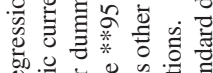

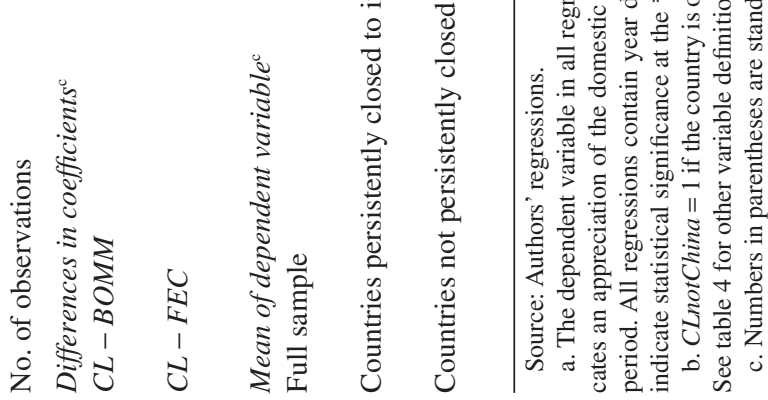

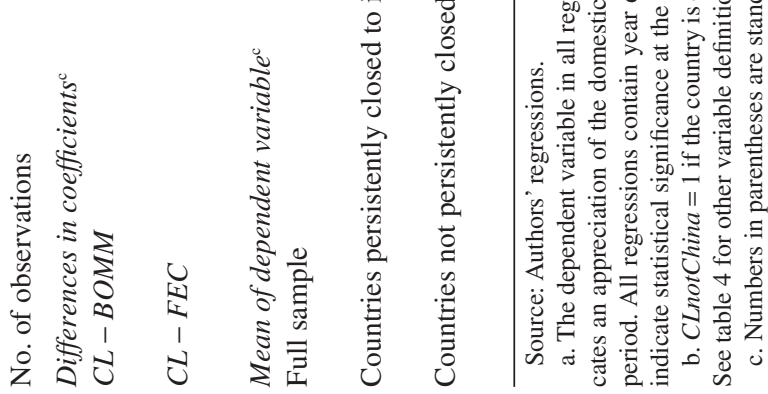


Figure 4. Capital Inflow Controls and Exchange Rates around QE2 in Five Emerging Market Economies, 2009-11

Exchange rate index ${ }^{\mathrm{b}}$

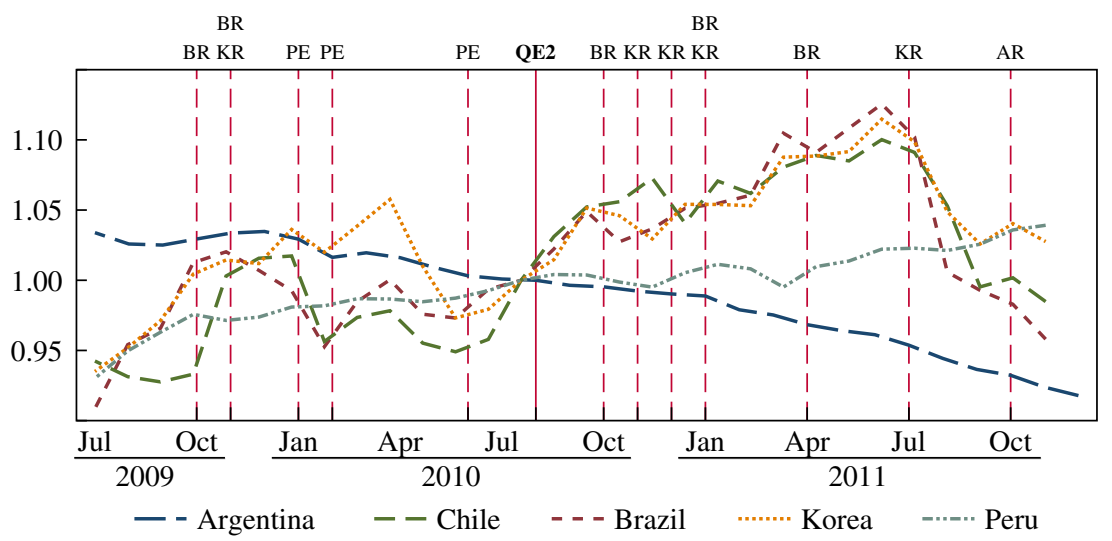

Source: Author's calculations

a. Vertical lines indicate the imposition or tightening of capital controls by Argentina (AR), Brazil (BR), Korea (KR), or Peru (PE); the line labeled "QE2" indicates the announcement of the second round of quantitative easing by the U.S. Federal Reserve.

b. Dollars per currency unit of the indicated country, indexed to equal 1.0 in August 2010.

Fed's annual Jackson Hole conference in August 2010, and more aggressive monetary easing began that fall. In the wake of the August announcement, some emerging market currencies began to appreciate against the dollar. In response, Brazil and South Korea undertook actions to stem the appreciation of their currencies in the fall of 2010 and through the summer of 2011.

Figure 4 presents a monthly index of the nominal dollar exchange rate for five countries-Argentina, Brazil, Chile, Korea, and Peru—between July 2009 and October 2011. The August 2010 QE2 announcement date is indicated, as are the dates of the imposition of controls on capital inflows. The figure shows that the currencies of Brazil, Chile, and Korea, which had begun appreciating earlier in the summer of 2010, continued to appreciate after the Bernanke announcement and through the autumn as QE2 was implemented. The appreciation of the won and the real did not show evidence of abating as the Brazilian and Korean governments imposed controls through that autumn and through the first half of 2011. The Chilean peso followed the appreciation of the won and the real, while the Argentine peso depreciated and the Peruvian nuevo sol stayed relatively constant. In 
July 2011, after the Korean authorities raised controls on inflows for the fourth time since the QE2 announcement, the Korean currency as well as those of Brazil and Chile began to depreciate. But the earlier impositions of controls were not effective, and it is difficult from the evidence presented in this figure to assert that episodic capital controls systematically affected currency values during this period.

\section{Conclusions}

The sharp exchange rate movements, asset price booms and busts, and general economic volatility of the past few years have prompted a search for a better way to manage economies. Controls on capital inflows have been receiving increasing support in policy circles, among researchers, and in the general economic debate. Theoretical research provides rationales for the imposition of episodic controls at times of surging capital inflows, or when the economy is booming. Long-standing controls receive little or no theoretical support. Yet much of the policy debate does not distinguish between the effects of long-standing controls and those of episodic controls, although implicitly the debate is about the imposition of episodic controls, not about permanently disengaging a country from the world capital market.

Part of the reason for this lack of distinction between the two types of controls has been a lack of research into the possible differences between them. This paper is an effort to fill that gap. The analysis has demonstrated some differences in the effects of long-standing and episodic capital controls, but for the most part these differences disappear, and neither type of capital control is found to be significantly associated with aggregate economic variables, once one accounts for the fact that countries with longstanding controls on capital inflows are poorer than the other countries in the sample. Thus, this preliminary evidence does not show that controls on capital inflows provide an effective policy option.

\section{APPENDIX}

\section{Capital Controls by Country and Asset Category}

Each cell of table A.1 reports the years in which a country had controls in place for the indicated category of assets, with "Open" signifying no controls during the entire 1995-2010 period and "Closed" signifying controls 


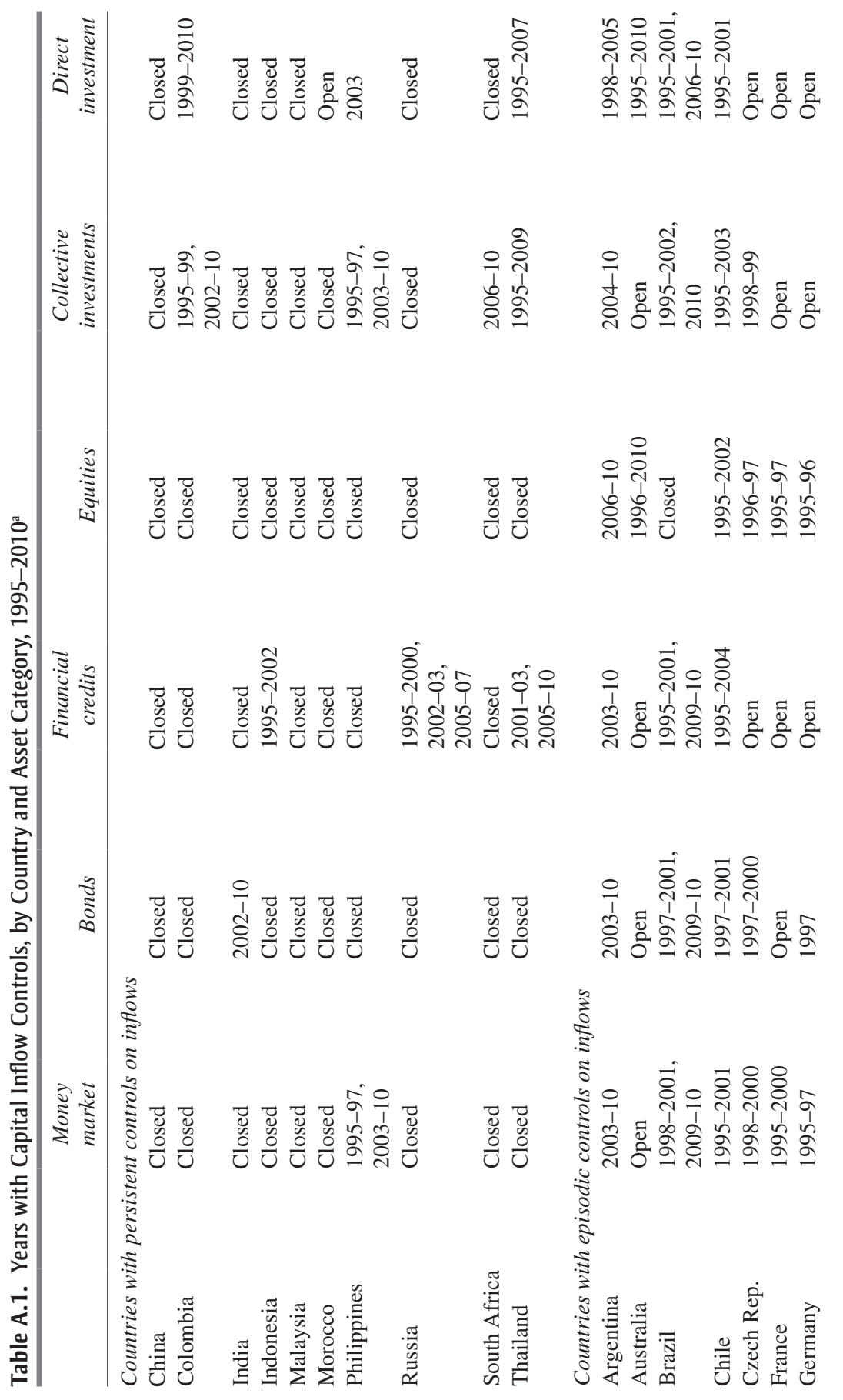




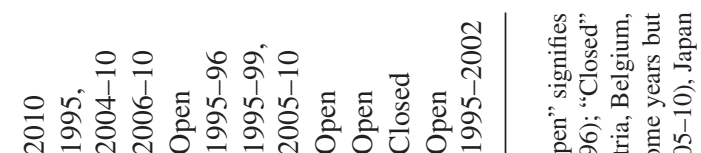

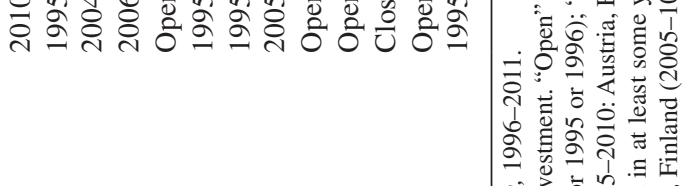

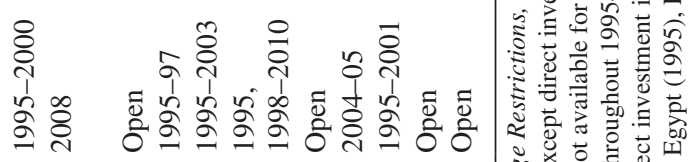

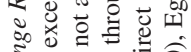

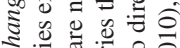

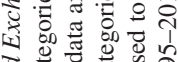

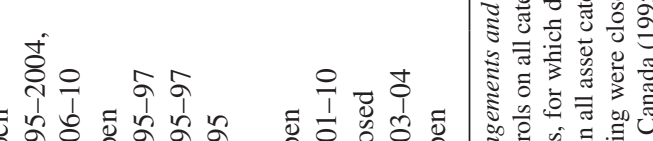

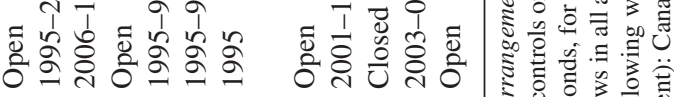

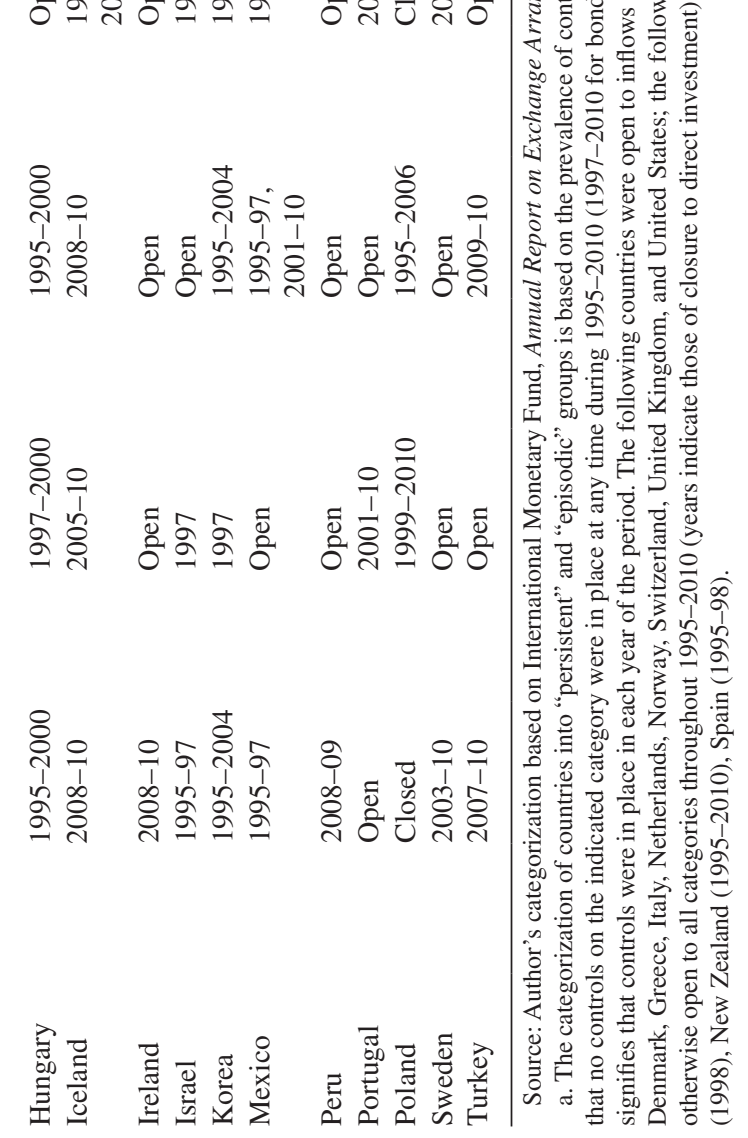


in place throughout the period (1997-2010 for bonds, since data on this category are not available for 1995 or 1996).

ACKNOWLEDGMENTS I thank Charles Collyns, Kristin Forbes, Jeff Frieden, Maury Obstfeld, Jonathan Ostry, Iván Werning, and the editors for comments on an earlier draft, and Dennis Quinn for making his most recent data set available. A special thanks to Patrick O'Halloran, who provided excellent research assistance. 


\section{References}

Bhagwati, Jagdish. 1998. "The Capital Myth: The Difference between Trade in Widgets and Trade in Dollars." Foreign Affairs 77: 7-12.

Bianchi, Javier. 2011. "Overborrowing and Systemic Externalities in the Business Cycle." American Economic Review 101, no. 7: 3400-26.

Bianchi, Javier, and Enrique Mendoza. 2010. "Overborrowing, Financial Crises and 'Macro-Prudential' Taxes.” Working Paper no. 16091. Cambridge, Mass.: National Bureau of Economic Research.

De Gregorio, José, Sebastian Edwards, and Rodrigo Valdés. 2000. "Controls on Capital Inflows: Do They Work?" Journal of Development Economics 63: 59-83.

Dornbusch, Rudiger. 1998. "Capital Controls: An Idea Whose Time Is Gone." Massachusetts Institute of Technology.

Edison, Hali, Michael Klein, Luca Ricci, and Torsten Sløk. 2004. "Capital Account Liberalization and Economic Performance: Survey and Synthesis." IMF Staff Papers 51, no. 2: 220-56.

Fischer, Stanley. 2003. "Globalization and Its Challenges." American Economic Review Papers and Proceedings (May): 1-30.

Forbes, Kristin, and Francis Warnock. Forthcoming. "Capital Flow Waves: Surges, Stops, Flight and Retrenchment." Journal of International Economics.

Forbes, Kristin, Marcel Fratzscher, Thomas Kostka, and Roland Straub. 2012. "Bubble Thy Neighbor: Portfolio Effects and Externalities from Capital Controls." Working Paper no. 18052. Cambridge, Mass.: National Bureau of Economic Research (May).

Ghosh, Atish R., Jun Kim, Mahvash Qureshi, and Juan Zalduendo. 2012. "Surges.” IMF Working Paper no. WP/12/22. Washington: International Monetary Fund (January).

Habermeier, Karl, Annamaria Kokenyne, and Chikako Baba. 2011. "The Effectiveness of Capital Controls and Prudential Policies in Managing Large Inflows." IMF Staff Discussion Note no. SDN/11/14. Washington: International Monetary Fund.

IMF Strategy, Policy and Review Department. 2011. "Recent Experiences in Managing Capital Inflows-Cross-Cutting Themes and Possible Policy Framework." Washington: International Monetary Fund.

Jeanne, Olivier. 2011. "Capital Account Policies and the Real Exchange Rate." Johns Hopkins University (February).

_ 2012. "Capital Flow Management." American Economic Review Papers and Proceedings (May): 203-06.

Jeanne, Olivier, and Anton Korinek. 2010. "Managing Capital Flows: A Pigouvian Taxation Approach." American Economic Review Papers and Proceedings (May): 403-07.

Jeanne, Olivier, Arvind Subramanian, and John Williamson. 2012. Who Needs to Open the Capital Account? Washington: Peterson Institute for International Economics. 
Keynes, John Maynard. 1920. The Economic Consequences of the Peace. New York: Harcourt, Brace and Howe.

Klein, Michael W., and Giovanni Olivei. 2008. "Capital Account Liberalization, Financial Deepness and Economic Growth.” Journal of International Money and Finance 27, no. 6: 86-75.

Korinek, Anton. 2010. "Regulating Capital Flows to Emerging Markets: An Externality View." University of Maryland (December).

- 2011. "The New Economics of Prudential Capital Controls: A Research Agenda." IMF Economic Review 59, no. 3: 523-61.

Kose, M. Ayhan, Eswar Prasad, Kenneth Rogoff, and Shang-Jin Wei. 2009. "Financial Globalization: A Reappraisal.” IMF Staff Papers 56, no. 1 (April): 8-62.

Obstfeld, Maurice. 1994. "Risk-Taking, Global Diversification, and Growth." American Economic Review 84, no. 5: 1310-29.

Obstfeld, Maurice, and Kenneth Rogoff. 1996. Foundations of International Macroconomics. MIT Press.

Organisation for Economic Co-operation and Development. 2009. Code of Liberalization of Capital Movements. Paris.

Ostry, Jonathan, Atish Ghosh, Karl Habermeier, Marcos Chamon, Mahvash S. Qureshi, and Dennis B. S. Reinhardt. 2010. "Capital Inflows: The Role of Controls.” IMF Staff Position Note no. SPN/10/04. Washington: International Monetary Fund.

Ostry, Jonathan, Atish Ghosh, Karl Habermeier, Luc Laeven, Marcos Chamon, Mahvash S. Qureshi, and Annamaria Kokenyne. 2011a. "Managing Capital Inflows: What Tools to Use?" IMF Staff Discussion Note no. SDN/11/06. Washington:International Monetary Fund.

Ostry, Jonathan, Atish Ghosh, Marcos Chamon, and Mahvash S. Qureshi. 2011b. "Capital Controls: When and Why." IMF Economic Review 59, no. 3: 562-80.

—. 2012. "Tools for Managing Financial-Stability Risks from Capital Inflows." Journal of International Economics 88, no. 2: 407-21.

Quinn, Dennis. 1997. “The Correlates of Change in International Financial Regulation." American Political Science Review 91, no. 3 (September): 531-51.

Quinn, Dennis, Martin Schindler, and A. Maria Toyoda. 2011. “Assessing Measures of Financial Openness and Integration." IMF Economic Review 59, no. 3: 488-522.

Rodrik, Dani. 1998. "Who Needs Capital-Account Convertibility?" In Should the IMF Pursue Capital-Account Convertibility? edited by Stanley Fischer and others. Essays in International Finance no. 207. International Finance Section, Department of Economics, Princeton University.

Rogoff, Kenneth S. 2002. "Rethinking Capital Controls: When Should We Keep an Open Mind?" Finance and Development (December): 55-56.

Sachs, Jeffrey, and Andrew Warner. 1995. "Economic Reform and the Process of Global Integration." BPEA, no. 1: 1-118.

Schindler, Martin. 2009. "Measuring Financial Integration: A New Data Set." IMF Staff Papers 56, no 1: 222-38. 
Shambaugh, Jay C. 2004. "The Effect of Fixed Exchange Rates on Monetary Policy." Quarterly Journal of Economics 119, no.1: 301-52.

Skidelsky, Robert. 1992. John Maynard Keynes: The Economist as Saviour, 1920-1937. London: Macmillan.

Stiglitz, Joseph. 2002. Globalization and Its Discontents. New York: W. W. Norton.

Summers, Lawrence. 2000. "International Financial Crises: Causes, Prevention, and Cures." American Economic Review 90, no. 2 (May): 1-16.

Tobin, James. 1978. "A Proposal for International Monetary Reform." Eastern Economic Journal (July/October): 153-59. 


\section{Comments and Discussion}

\section{COMMENT BY}

KRISTIN J. FORBES The desirability of capital controls has been debated for decades. My discussion begins by placing this paper by Michael Klein in the context of this important debate. I then consider some details of Klein's analysis, highlighting the important contribution made by the data and several econometric issues that need to be addressed in order for the results to shift views on the desirability of episodic capital controls. I conclude by raising a key question that will, I hope, be addressed in future work in order to clarify exactly what determines the efficacy of capital controls.

THE CONTEXT My figure 1 shows that net capital flows to emerging markets have increased dramatically since the early 2000s, and that these flows can be extremely volatile. These large and volatile flows can present substantial challenges for many countries-especially those with weaker and less developed financial markets. For example, large net inflows of capital can cause sharp currency appreciations, reducing competitiveness, increasing trade deficits, and causing Dutch disease. They can increase the money supply and liquidity, generating inflation, overheating of the economy, inefficient lending, and bubbles in housing and other markets. Research has shown that such surges are correlated with real estate booms, banking crises, debt defaults, inflation, and currency crises. Just as challenging can be the "sudden stops," when the capital inflows dry up, which research shows are correlated with currency depreciations, slower growth, and higher interest rates.

Policymakers faced with these dangers from large and volatile capital inflows are constantly challenged as to how best to respond. There are a number of standard policy responses-such as lowering interest rates, tightening fiscal policy, allowing the currency to appreciate, accumulating reserves, and encouraging capital outflows. But each of these has 
Figure 1. Net Private Capital Flows to Emerging Markets, 1990-2012

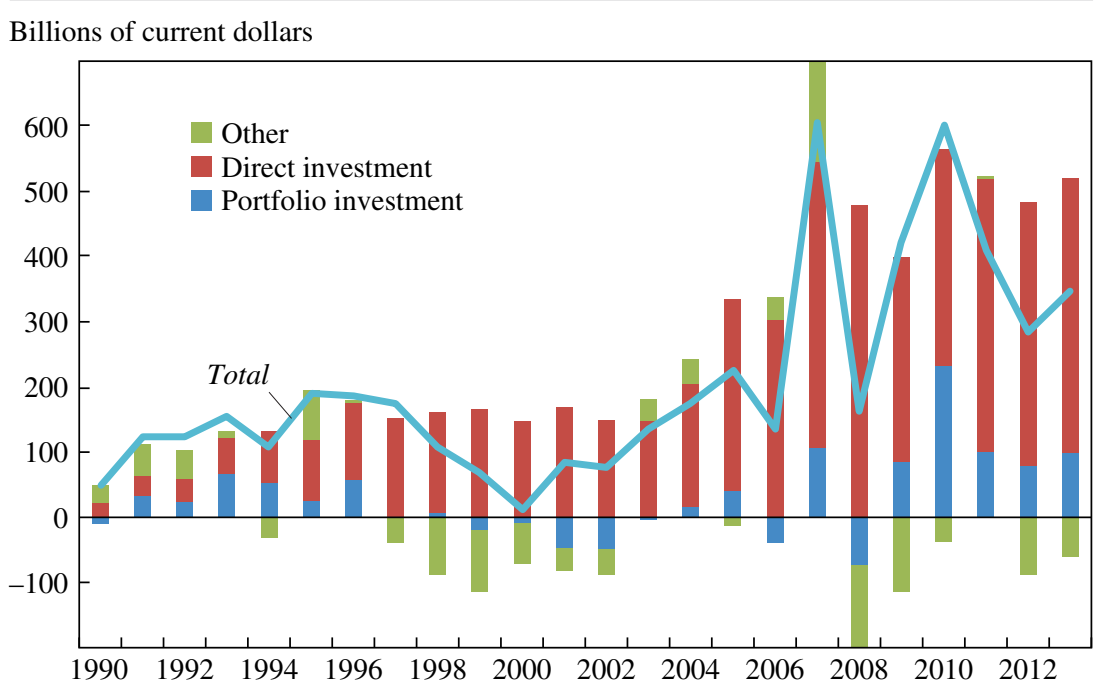

Source: International Monetary Fund, World Economic Outlook database. a. Data exclude changes in reserves and official capital flows.

significant limitations or costs, as my table 1 shows. These extremely limited options have forced a fundamental rethinking of other strategies. Two that have received substantial attention are macroprudential regulation and temporary controls on capital inflows (what Klein calls "episodic" controls).

There is by now fairly widespread agreement that macroprudential regulations should have a role in managing large and volatile capital inflows, as well as in strengthening the overall financial system. Constructing the appropriate regulations, however, is extremely difficult for technical reasons. Even if it were possible to design the optimal regulations, garnering political support for them has been challenging in many countries with strong financial lobbies.

Given the limitations of other policies, the use of episodic controls on capital inflows has garnered recent support from a number of sources. Several emerging markets viewed as market friendly and supportive of foreign investment have recently used these controls. (A prominent example is Brazil's use of the Imposto sobre Operacões Financieras, or IOF, in 2010 and 2011.) Even the International Monetary Fund (IMF), formerly a bastion of capital market liberalization, has supported capital controls in certain circumstances as part of the "policy toolkit" (Ostry and others 
Table 1. Options for Managing Surges of Capital Inflows

\begin{tabular}{lc}
\hline Policy & \multicolumn{1}{c}{ Potential limitations and costs } \\
\hline Lower interest rates & $\begin{array}{c}\text { Inflation, asset price bubbles, overheating, increased risks } \\
\text { to overall financial system } \\
\text { Appreciation of domestic currency, political challenges, } \\
\text { possible reduction in investment which reduces future } \\
\text { growth }\end{array}$ \\
$\begin{array}{l}\text { Harm to competitiveness, Dutch disease effects } \\
\text { appreciation }\end{array}$ \\
$\begin{array}{l}\text { Accumulate reserves } \\
\text { Encourage capital outflows }\end{array}$ & $\begin{array}{c}\text { Increasing cost, inefficient allocation of resources, } \\
\text { multilateral concerns } \\
\text { Often limited impact, possible undermining of domestic } \\
\text { financial stability in future }\end{array}$ \\
\hline
\end{tabular}

2011). Several empirical papers have shown that taxes on capital inflows can reduce financial vulnerabilities by changing the composition (albeit not the volume) of inflows. The argument for controls has also been bolstered by a series of theoretical papers modeling the various ways in which taxes on capital inflows can be optimal in the presence of other distortions. ${ }^{1}$

Klein's paper, however, presents a serious challenge to this sea change in support of episodic controls on capital inflows. His results show that capital controls do not work if they are episodic. He argues that long-term and widespread capital controls ("walls") may have some effect, but any controls that are viewed as temporary ("gates") will not reduce financial vulnerabilities. This directly undermines the key arguments made in support of episodic controls by institutions such as the IMF. His results also show that episodic controls do not significantly moderate currency appreciation. This directly undermines the key arguments made in support of episodic controls by most policymakers who have used these controls. Therefore, if the results of Klein's analysis withstand the test of time and are shown to be robust, they raise serious questions about the use of episodic capital controls.

THE ANALYSIS One of the major challenges with empirical work on capital controls is how to translate the controls actually in use into a numerical measure that can be used for cross-country analysis. Different countries have very different structures of controls (for example, some impose taxes on capital flows whereas others set quantity limits) and target different

1. For example, see Korinek (2010), Jeanne and Korinek (2010), and Costinot, Lorenzoni, and Werning (2011). 
types of capital flows (such as equity or debt). Controls that are nominally identical may be enforced to varying degrees in different countries, and their effectiveness may vary depending on what other controls are in place and on the sophistication of the country's financial market. These problems in constructing measures that are comparable across countries have made it extremely difficult to find robust effects of capital controls (see Forbes 2007).

Over the past few years, however, several new measures of capital controls have been developed in an attempt to better quantify the different control regimes. Klein's paper builds on this work and makes a critically important extension. Several papers (such as Schindler 2009) address the measurement problem by differentiating among controls according to the type of capital flow being targeted. Klein highlights the importance of this differentiation and updates Schindler's measures; this is itself an important contribution to the literature, as the previous data set has quickly become outdated. Klein's most important contribution, however, is his argument that capital controls also need to be differentiated according to whether they are permanent or episodic. To the best of my knowledge, this differentiation is mentioned in only one other paper (Forbes and others 2012) — and then only as a minor point made for a different purpose. Klein discusses why this differentiation could be important in assessing the effectiveness of controls and describes a new database of episodic controls that he has developed. The distinction is indeed extremely important, and future work on capital controls should incorporate it.

Klein then uses his new database to estimate the impact of episodic and permanent capital controls on financial vulnerabilities, GDP growth, and the real exchange rate. Estimating these relationships is extremely challenging, but nonetheless important for a better understanding of whether episodic controls can affect any of these variables. My biggest concern with Klein's current framework relates to timing and endogeneity. His measures of capital controls are constructed at an annual frequency, but in practice controls are often adopted and adjusted at much higher frequencies. For example, Brazil raised its tax on foreign investment in bonds twice within the same month in 2010. Such adjustments are believed to have immediate effects on financial variables, and these effects may be difficult to capture many months after the policy changes-especially when one cannot control for the counterfactual over such long periods. For example, Forbes and others (2012) find that changes in Brazil's capital controls affect capital flows only briefly — over a period of 3 months—and have no effect over longer periods. 
Figure 2. The IOF and Net Portfolio Investment Inflows in Brazil, 2001-10

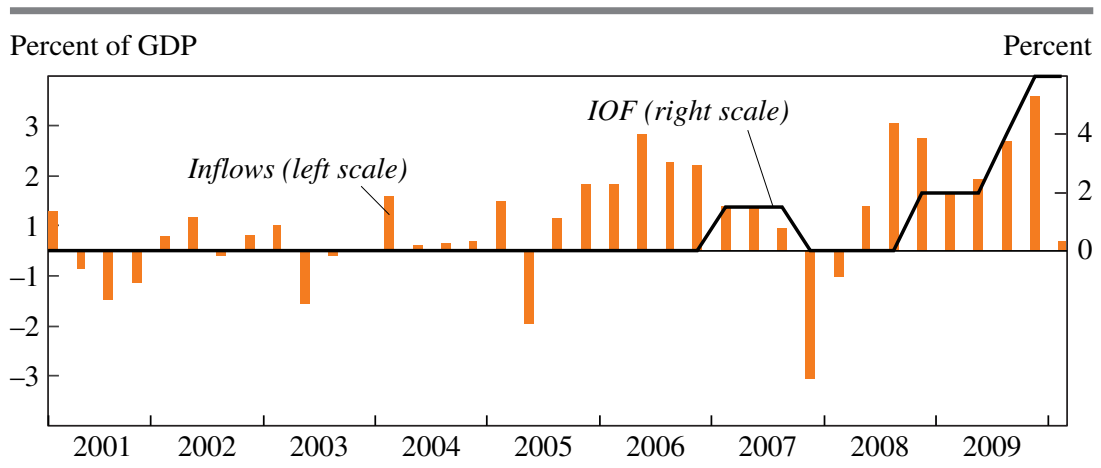

Source: Reprinted from Forbes and others (2012, p. 46), using data from International Monetary Fund, Balance of Payments Statistics. Accessed online October 30, 2011.

A closely related point is that changes in capital controls are often made in response to changes in variables such as capital inflows or the exchange rate. Therefore any estimation of their effects on these variables needs to seriously consider endogeneity. For example, my figure 2 plots net portfolio inflows (equity and debt) into Brazil and the level of the IOF on debt (the tax on purchases of debt by foreigners) over the decade starting in March 2001. The figure clearly shows that Brazil tends to increase this capital control after inflows increase and to lower it when inflows drop sharply. Thus, any attempt to estimate the impact of the IOF on capital inflows without controlling for endogeneity would yield estimates that are biased downward, indicating less of an effect than actually occurs. Finding valid instruments to control for this endogeneity is extremely difficult. Aware of this issue, Klein also reports regressions that include lagged values of the controls. I am worried, however, that this strategy could actually aggravate any biases, especially given the very imprecise timing of the relationship between controls and the left-hand-side variables due to the annual frequency of the data.

Another question about Klein's estimation strategy is whether a country that enacts episodic controls might, by doing so, change how it is perceived by investors in a way that persists even after the controls are removed. For example, Forbes and others (2012) find that a key channel by which capital controls affect investor portfolios is through signaling. When Brazil raised its IOF on foreign investment in bonds, equity investors also reduced their portfolio allocations to Brazil, even though the change imposed no direct cost on them. There can be contagion effects as well: Brazil's move also led 
investors to decrease their portfolio allocations to other countries viewed as "control friendly." In the Klein paper, any of these effects could bias the results toward finding less of an effect of episodic capital controls, as the current estimation strategy assumes that lifting or reducing controls would return the country to its initial, "control free" status.

A final consideration for the empirical analysis is the need to perform careful robustness tests. As anyone who has worked in this literature is aware, results are often highly sensitive to a few outliers. In other work, simple changes such as excluding the Baltic countries have significantly affected results. (This is not a concern in Klein's paper, however, as the Baltics are not in the data set.) Given the extremely small number of countries that have used episodic controls, it is critically important to ensure that results are not driven by outliers. It is also worth carefully checking whether one's results are robust to different definitions of episodic controls. For example, Klein classifies Colombia and Thailand as having persistent controls, but in interviews performed for Forbes and others (2012), investors generally classified Colombia as being open, market friendly, and not supportive of controls. Similarly, Thailand is often cited as an example of temporary controls (such as its very short term tax on investment in equities in December 2006). Any classification will be subject to disagreement, but it would be useful to see whether any simple changes - such as matching classifications more closely to investors' perceptions-affect the results.

CONCLUSION-AND A QUESTION This paper makes what will surely be a lasting contribution to the extensive literature on capital controls. In the wake of Klein's arguments and results, any future analysis of capital controls should differentiate whether the controls are intended to be episodic or persistent. These different types of controls could have significantly different effects on key variables. Klein's empirical analysis uses this new differentiation to find that episodic controls are not effective in reducing financial fragility, raising GDP growth, or moderating domestic currency appreciation. In other words, he finds no evidence to support the recent shift in support of episodic controls to reduce financial fragilities and moderate currency appreciation (both of which would be expected to improve growth over longer periods). If these results hold up to further scrutiny,

2. The sample of "control friendly" countries used in Forbes and others (2012) includes not only countries with long-standing controls, but also countries that have used episodic controls at any point in the past. A series of interviews with investors conducted for the project also indicated that certain countries had a stigma of being "control friendly" and less investor friendly, even if they were not currently using controls. 
they present a serious challenge for the greater use of episodic controls on capital inflows to mitigate the problems from large and volatile inflows.

For the results in this paper to convince policymakers of the ineffectiveness of episodic controls, however, it will be necessary to strengthen the econometric analysis in several directions. Issues such as the timing of effects, endogeneity, a permanent signaling effect of episodic controls, and extensive robustness tests will be important to bolster the arguments.

Finally, the results leave this reader with a critically important question: why are episodic controls less effective than persistent controls? The paper presents a number of hypotheses; for example, episodic controls may be easier to evade or allow easier switching between types of capital flows. Some of these mechanisms should be straightforward to test. For example, if foreign investors classify their equity investment as direct instead of portfolio investment in order to avoid a tax on the latter, any observed reduction in aggregate portfolio equity flows should be balanced by an increase in direct investment flows. Other behavioral responses might be possible to capture by differentiating among types of investor according to their ability to use different tax avoidance techniques. Having a better understanding of exactly how this could occur would be an important contribution in clarifying exactly why episodic controls function differently. Additional evidence on why episodic controls are ineffective would further strengthen the key contribution of this paper, which is that any future analysis of capital controls should distinguish not only between the types of capital flow being targeted, but also between controls of different durations.

\section{REFERENCES FOR THE FORBES COMMENT}

Costinot, Arnaud, Guido Lorenzoni, and Iván Werning. 2011. "A Theory of Capital Controls as Dynamic Terms-of-Trade Manipulation.” Working Paper no. 17680. Cambridge, Mass.: National Bureau of Economic Research.

Forbes, Kristin. 2007. "The Microeconomic Evidence on Capital Controls: No Free Lunch." In Capital Controls and Capital Flows in Emerging Economies: Policies, Practices, and Consequences, edited by Sebastian Edwards. University of Chicago Press.

Forbes, Kristin, Marcel Fratzscher, Roland Straub, and Thomas Kostka. 2012. "Bubble Thy Neighbor: Portfolio Effects and Externalities from Capital Controls." Working Paper no. 18052. Cambridge, Mass.: National Bureau of Economic Research.

Jeanne, Olivier, and Anton Korinek. 2010. "Managing Credit Booms and Busts: A Pigouvian Taxation Approach." Working Paper no. 16377. Cambridge, Mass.: National Bureau of Economic Research.

Korinek, Anton. 2010. "Regulating Capital Flows to Emerging Markets: An Externality View." University of Maryland. 
Ostry, Jonathan, Atish Ghosh, Karl Habermeier, Marcos Chamon, Mahvash Qureshi, and Dennis Reinhardt. 2010. "Capital Inflows: The Role of Controls." IMF Staff Position Note no. 10/04. Washington: International Monetary Fund.

Schindler, Martin. 2009. "Measuring Financial Integration: A New Data Set.” IMF Staff Papers 56, no. 1: 222-38.

\section{COMMENT BY}

IVÁN WERNING This paper by Michael Klein takes on the nearly impossible task of evaluating the usefulness of capital controls by employing cross-country regressions. Not surprisingly, the paper's results fall short of conclusively answering this question.

The shortcomings of cross-country regressions at establishing anything other than descriptive patterns and correlations is well appreciated. In fairness, this problem is not specific to this paper but is shared by most of the existing literature on capital controls that takes the cross-country regression approach. Indeed, relative to that literature, this paper makes important contributions by improving the data series used, distinguishing controls on inflows from those on outflows, and distinguishing among controls on different asset classes. It also separates those countries that are permanently closed to capital inflows from those that have used capital controls temporarily. All this pushes the literature in positive directions.

Unfortunately, neither the improved and extended data nor the distinction between permanent and episodic uses of capital controls helps resolve the essential problems one faces in interpreting cross-country regressions. One still cannot draw firm conclusions about the key economic policy question the paper set out to investigate. For this particular application, two problems are most important.

The first is a selection problem. As the paper establishes, countries that have employed capital controls episodically look quite different from those that have adopted them permanently, and quite different from those that have abstained from controls altogether. What is it that leads some countries and not others to use capital controls? In general, the differences that one finds between the two groups may affect their economic outcomes directly, making interpretation of the coefficients on the capital controls variables difficult. At least until recently, capital controls were typically introduced during desperate times by the misfits of the world; so this may be a very select sample.

The second is a potentially severe endogeneity problem. Consider the following hypothetical example. Country A learns that large capital inflows 
are headed its way for the next 3 years; its policymakers act quickly to introduce capital controls, which block the inflows and prevent a real appreciation. Country B experiences no such shock; it does not introduce capital controls and its real exchange rate remains unchanged. Comparing the outcomes of A and B is obviously meaningless.

To deal with this problem, the paper lags all its capital control measures. Unfortunately, only under very special conditions will the use of lagged variables resolve endogeneity problems while continuing to estimate anything of interest. In my hypothetical example, both the shock and the policy response were persistent, so lagging the policy variable is not helpful.

Although at one point well into the paper Klein acknowledges these problems, for the most part he seems content to interpret the regressions as evidence against the efficacy of capital controls. Such a conclusion is completely unwarranted.

A few other issues, unrelated to the problem of interpreting the crosscountry regressions, also make me hesitate to draw sharp conclusions from the regressions presented in this paper. The first issue relates to the gap between capital controls in theory and capital controls in practice. This paper is partly motivated as an evaluation of recent theories that advance the idea that episodic capital controls may improve welfare. But what do we really learn about this from Klein's regressions? Taken at face value, one possible interpretation for his results is that controls have had no effects because they have not been enforced properly and have been largely evaded. Under this interpretation the policies advocated by these recent theories have not, strictly speaking, actually been tested. There are two possible reactions. On the one hand, if one takes this as proof that episodic capital controls have no hope of ever being effectively enforced, then this obviously makes these policies and theories irrelevant. On the other hand, the evidence may simply suggest the importance of more careful thinking and planning for the implementation of controls. Similar comments apply if controls were actually enforced, but applied incorrectly, perhaps in the wrong situations, for example. In short, because we have only the experience of actual policy, and not of ideal policy, the question of whether recent theories about capital controls are useful guides for policy may be very hard to answer.

Another issue is that the paper suggests the wrong sign for the effects of capital controls on growth in GDP. The theories that feature a beneficial role for capital controls do not imply that their introduction leads to more rapid growth in GDP. Indeed, according to these models, if controls are exogenously introduced, then the immediate effect on economic activity is contractionary. I do not think this is controversial. Indeed, it is also part 
of the conventional wisdom that controls lower credit supply and that this lowers economic activity. All this suggests lower, instead of higher, rates of GDP growth shortly after the introduction of controls.

Yet Klein's paper argues that these theories must predict higher growth in GDP to deliver their promised higher welfare. As I just argued, this is clearly wrong in the short run, which is likely to be the horizon over which the important episodes during 2008-10 transpired. However, what about the average effect on growth over a longer horizon? Actually, these theories do not predict more rapid average growth even over the long run. The reason is that the welfare gains from the optimal use of controls in these models are delivered by lowering the volatility of economic activity, not by increasing GDP growth.

Let me conclude with two smaller points regarding the statistical significance of Klein's results. First, the capital controls series, constructed by taking ad hoc averages over various indexes, can only be interpreted as at best a proxy for the economic costs and barriers imposed on capital inflows. This raises the real possibility that classical measurement error is biasing the estimated coefficients toward zero. Second, even with estimated coefficients that are not statistically different from zero, the confidence intervals may include economically significant numbers. For example, in Klein's table 4 the statistically significant coefficients for the regression in column 4-1 fall within the confidence intervals for the regression in column 4-2. Both these points, I think, are worth keeping in mind when reading Klein's regressions.

GENERAL DISCUSSION John Williamson saw the paper's main contribution as its distinction between permanent and episodic capital controls, and he agreed that the latter were of greater interest. However, he read the paper's evidence not as demonstrating that episodic capital controls do not work, but rather as inconclusive either way, because of the endogeneity problem that both formal discussants had cited. Williamson also argued that the period from 2007 to 2010 was not a good one for testing the efficacy of inflow controls, because by and large that period was not one of large capital inflows in the countries studied. Finally, Williamson noted that although an extensive literature has examined the Chilean experience with controls, with mixed results, the paper cited from that literature only one study, one that supported the author's view.

Ricardo Reis called for a clearer distinction in the paper between, on the one hand, official interventions in capital transactions generally, both domestic and international, and on the other, interventions in foreign 
capital transactions only. Without such a distinction between broad financial repression and repression of capital inflows only-a distinction that the author's data set seemed to allow-the empirical results were difficult to interpret. Reis also pointed out that even those countries regarded as most liberal in their treatment of capital flows did impose some limits on foreign acquisition of some types of assets: the United States, for example, from time to time blocks the acquisition of companies deemed vital to the national interest. This, Reis argued, did not invalidate this type of analysison the contrary, the additional variation resulting from such actions might help in assessing the effectiveness of controls.

Gerald Cohen seconded the concern about endogeneity but suggested that the impact of controls on the exchange rate could be estimated more precisely if one assumed that the scope of the controls is chosen so as to offset the positive carry, or the spread between domestic and foreign interest rates.

Martin Feldstein questioned the assertion that Brazil's use of controls had not succeeded in lowering the exchange value of the country's currency. As prima facie evidence he cited the most recent issue of The Economist, which reported that the real had in fact depreciated by some 25 percent in the last 12 months.

David Romer noted that a separate question from whether capital controls can work in principle, under optimal circumstances, is whether capital controls in practice have been imposed in timely fashion. All of the paper's analysis addresses the first question, leading Romer to wonder whether the data could also shed any light on the second.

Returning to Iván Werning's point about prudential concerns as a possible motivation for capital controls, Michael Kiley raised the question of why countries would use capital controls for that purpose when other measures were available. Indeed, some countries, especially in Asia, had imposed limits on loan devaluations and restrictions on real estate transactions as a substitute for, or a complement to, capital controls. He speculated that the reason for continuing to use capital controls in these circumstances was the scarcity of evidence that these alternative macroprudential measures were any more effective.

Joseph Gagnon challenged Kristin Forbes's claim that international capital flows to developing countries had grown more rapidly in the 2000s than before. His own calculations indicated that, scaled to recipient-country GDP, capital inflows were actually smaller in the 2000s than in the 1990s. Gagnon also pointed out that developing countries today were borrowing increasingly in their own currencies, rather than in dollars or euros, and he 
wondered what impact that might have on those countries' policies regarding capital controls.

Justin Wolfers raised a caveat regarding the measurement of capital controls, namely, that actual official practice might differ from what is set down in the law or regulation. Australia, for example, has a Foreign Investment Review Board with certain enumerated powers and responsibilities but, from what Wolfers could see, does essentially nothing.

Responding to the discussion, Michael Klein noted that some countries might resort to capital controls as a macroprudential tool because they lack adequate resources for bank regulation and supervision. Often, however, the distinction between what is a prudential regulation and what is a capital control was less than clear, and the two can overlap. He added that when capital controls are put in place simultaneously with other kinds of financial regulation, it would, if anything, bias his analysis toward finding an effect of capital controls. He had approached the question with an open mind and had in fact been surprised to find such weak effects.

Turning to the endogeneity question, Klein said he had spent considerable time looking for a valid instrument for the imposition of controls to use in his regressions, without success. Part of the problem, he suggested, was that his data were of annual frequency-it would be difficult to construct a data set of controls at shorter frequency. In any case, if one did find an effect at shorter frequencies-say, at two months-Klein questioned whether that would be of any interest from a policy perspective.

Replying to Forbes's point that a country's imposition of controls might shift investors' perception of it from being a controls-unfriendly to a controls-friendly country, thus amplifying the effects, Klein pointed out that few, if any, of the countries in his sample had never used capital controls. Given its history, investors were, or should have been, on guard that Brazil, for example, might suddenly impose controls.

Replying to Gagnon, Klein thought that borrowing in one's own currency would largely obviate the need for capital controls, but he acknowledged that his data did not distinguish between such controls and controls on foreign-currency borrowing.

Replying to Reis, Klein said he had chosen not to distinguish in his analysis between residents and nonresidents because his initial calculations indicated that it made no difference to the results. He thought, however, that the kinds of direct investment restrictions that Reis had cited, involving individual companies or industries, had little to do with the issues of currency appreciation or macroprudential regulation that were the motivations behind the kinds of controls that were the focus of this study. 